\title{
APUNTES PARA UN ANÁLISIS ECOLÓGICO DE LAS FORMAS DE POLÍTICA CONTEMPORÁNEAS
}

\author{
DAVID SAN MARTÍN SEGURA \\ Licenciado en Derecho \\ Universidad de La Rioja
}

\section{SUMARIO}

I. PlanteAmiENTO: 1. Ecología y política. 2. Ética ecológica: antropocentrismo, biocentrismo, o la realidad como proceso. 3. Una reflexión sobre la sustentabilidad. II. PROTECCIÓN JURÍDICA DEL AMBIENTE EN EL ESTADO DE DERECHO: 1. Breve descripción de la política ambiental en el Estado español. 2. Críticas y alternativas a la actual política ambiental. 3. Reconsideración del Estado moderno desde la perspectiva ecológica. III. ECOLOGÍA Y DEMOCRACIA: 1. ¿Un vínculo contingente o necesario? 2. Qué tipo de democracia para una sociedad sustentable. 3. Ecología y ciudadanía. IV. LA RESPUESTA NEOLIBERAL: ECOLOGÍA DE MERCADO. 1. Capitalismo, neoliberalismo y ecología. 2. Fundamentos de la Ecología de Mercado. 3. Crítica a la Ecología de Mercado. 4. Qué tipo de economía para una sociedad sustentable. V. CONCLUSIÓNES. VI. BIBLIOGRAFÍA.

\section{RESUMEN}

La cuestión ecológica nos sitúa ante el reto de construir una sociedad capaz de desarrollarse de forma sostenible con respecto a su entorno. Un proyecto de tal magnitud no puede abordarse mediante políticas superficiales que, como hasta ahora, sólo plantean la introducción de medidas correctoras en los sistemas productivos. Por un lado, es necesaria una revisión de la cosmovisión que sustenta nuestras actuales relaciones con los ecosistemas no humanos. Por el otro, las propias estructuras de organización social deben ser analizadas desde la perspectiva ecológica, a la búsqueda de los puntos débiles que puedan hacerlas inoperantes para plasmar el ideal de la sostenibilidad. Este artículo trata de aportar algunos elementos para el análisis de las actuales formas de política (Estado, democracia liberal, capital) desde la perspectiva 
ecológica, señalando sus graves deficiencias para alcanzar una sostenibilidad real, y esbozar algunos criterios para su superación.

\section{PLANTEAMIENTO}

\section{Ecología y política}

Aunque hoy pueda parecer extraño, hace sólo algunas décadas la palabra ecología era un término poco conocido, utilizado sólo en ciertos ámbitos científicos, y de forma muy aislada a nivel social. Durante cierto tiempo, el deterioro ecológico fue considerado simplemente el discurso de ciertas organizaciones tildadas de marginales y catastrofistas. Hoy, evidentemente, la situación ha cambiado. Los problemas ecológicos son tan explícitos que nadie, o casi nadie, los pone en duda, y existe una consciencia común de que la humanidad está llevando al planeta al límite de su capacidad de sustentación. Ninguna civilización ha visto tan cerca como la nuestra el precipicio de la autodestrucción.

Sin embargo, a pesar de esta consciencia común y de que los temas ambientales están muy presentes en la vida pública de nuestras sociedades, hasta el momento nos hemos mostrado incapaces de frenar esta destrucción irracional, o al menos no lo hemos conseguido en la medida suficiente como para evitar las fatales consecuencias que se prevén a corto y medio plazo. Ante lo cual surge la pregunta de ¿qué está fallando?.

Quizá el problema radique en que, tal y como ocurría hace años con el propio deterioro ecológico, no se ha logrado aún un sentir generalizado sobre la amplitud y profundidad del problema. Puede que, acuciados por adoptar medidas urgentes que traten de evitar la catástrofe del ocaso ambiental, hayamos olvidado la necesidad de analizar sus causas últimas, las raíces de la cuestión. Como consecuencia, parece haberse impuesto una lectura de los problemas ecológicos que ha alejado el debate de su núcleo fundamental. Esta particular visión ha consistido en plantear el problema en términos exclusivamente tecnológicos, enfocando la ecología desde una óptica científico-técnica, apartándola de otros ámbitos, como la política, la antropología o la sociología. Desde esta óptica, las soluciones que hasta ahora se han aportado han sido casi exclusivamente tecnológicas, dando soluciones a problemas puntuales, pero olvidando la gran amplitud de la ecología, y la variedad de factores -también políticos y sociales- que influyen sobre el ambiente.

El reto que nos plantea la cuestión ecológica es enorme; se trata de construir una forma de vida, una sociedad, capaz de desarrollarse de forma sostenible con respecto a su entorno, lograr reintegrar nuestras sociedades industrializadas en el ecosistema que las sustenta. No parece que un proyecto de tal magnitud pueda abordarse mediante políticas que sólo inciden en la superficie del problema, a través de la introducción de medidas correctoras en el sistema económico y nuevas técnicas en los procesos productivos. La situación exige ir más allá. Como ha propuesto un número creciente de autores, las propias estructuras de organización social deben ser analizadas desde la perspectiva ecológica, a la búsqueda de los puntos débiles que puedan hacerlas 
inoperantes para plasmar el ideal de la sostenibilidad. En la actualidad, cualquier enfoque político económico debe asumir el reto presentado por los problemas ecológicos.

Obviamente, este trabajo no pretende un análisis exahustivo en el sentido indicado, ni llegar a respuestas definitivas, porque además, es probable que no existan soluciones unívocas. Nuestro objetivo es aportar algunos elementos para el análisis de las actuales formas de política (Estado, democracia, capital) desde la perspectiva ecológica, exponiendo y confrontando las principales aportaciones realizadas al debate a lo largo de estas últimas décadas. Por ello el tono de la exposición será esencialmente descriptivo, aunque no renunciemos a extraer algunas conclusiones propias al respecto.

\section{2. Ética ecológica: antropocentrismo, biocentrismo, o la realidad como proceso}

Hablar de política o de economía desde la perspectiva ecológica supone un cambio epistemológico notable. Implica considerar estructuras específicamente humanas (formas conscientes de regulación social, asignación racional de los recursos existentes, etc.), integrando en el análisis factores o intereses que tradicionalmente han sido considerados ajenos a las mismas, al ser percibidos como algo externo al ecosistema humano. La Filosofía política y la Economía deben girar la mirada hacia procesos que habitualmente han sido definidos como naturales, en oposición a los aspectos sociales considerados su objeto de estudio, y revisar sus conclusiones a partir de los datos aportados por la Ecología ${ }^{1}$. En definitiva, supone ser conscientes de los lazos que interrelacionan sociedad y naturaleza. Por esta razón, cualquier reflexión ecopolítica remite a un plano axiológico previo en el que debe ser definido el sentido de esa relación, es decir, el concepto de naturaleza que manejaremos y su valoración en un sentido ético.

Desde esa perspectiva, la percepción de la naturaleza por el ser humano en las sociedades desarrolladas ha sido calificada como antropocéntrica, siendo éste un criterio ampliamente compartido por filósofos, antropólogos, etólogos, etc. La noción antropocéntrica de la realidad podría definirse como el conjunto de creencias que inducen a ver el mundo no humano sólo como un medio para los fines humanos, que la Tierra fue hecha para ser dominada por la humanidad, de lo que se deriva la concepción del hombre como rey de la creación ${ }^{2}$. Sería pues la doctrina o teoría que supone que el ser humano es el centro de todas las cosas y el fin absoluto de la naturaleza.

\footnotetext{
${ }^{1}$ No obstante, este planteamiento no es nuevo. En el ámbito de la Economía existe una corriente que ha rechazado desde hace décadas la división entre procesos sociales y procesos naturales, a raíz de la constatación del importante papel de las leyes de la termodinámica en los procesos productivos. Se trata de la denominada Economía ecológica, teoría forjada desde mediados del siglo pasado, pero cuyos precursores se remontan al siglo XIX, que encuentra su principal representante en el rumano Nicholas Georgescu-Roegen. En el ámbito político, cabe destacar la Ecología social, corpus teórico desarrollado desde los años cincuenta inicialmente por Murray Bookchin, que rechaza igualmente la oposición entre sociedad y naturaleza al analizar conceptos como democracia y Estado. Sin embargo, estas corrientes han permanecido como marginales dentro de la Filosofía política y económica.

${ }^{2}$ GORDILLO FERRÉ, J.L., "Del Derecho ambiental a la ecologización del Derecho", en VV.AA., Transformaciones del Derecho en la Mundialización, Escuela Judicial (CGPJ), Madrid, 2000, p. 332.
} 
Los datos aportados por la Antropología demuestran que tal concepción del mundo ha permanecido inalterada durante siglos. Dicha cosmovisión se habría originado en Mesopotamia, con el inicio de la práctica masiva de la agricultura ${ }^{3}$, siendo después heredada por el cristianismo, más tarde por el cientificismo renacentista y posteriormente por los filósofos de la Ilustración. También el individualismo radical que inspira todo el pensamiento liberal desde el siglo XVII, presenta esta visión antropocéntrica del mundo y de la ética, situando al individuo humano (masculino) en el centro de toda la realidad. Más aún, puede decirse que las teorías neoliberales, tan en auge en las últimas décadas del siglo XX y principios del XXI, representan la versión más radical del antropocentrismo a lo largo de toda la Historia de la humanidad.

A raíz de la intensificación de los problemas ecológicos a partir de los años setenta, han surgido planteamientos éticos ligados a distintos movimientos ecologistas y ambientalistas, que proponen una superación del principio antropocéntrico como paso ético irrenunciable previo a la formulación de cualquier propuesta ecológica. En esos términos ha sido desarrollada la ética biocéntrica, difundida de la mano de la llamada Ecología profunda (Deep ecology) ${ }^{4}$. Si el antropocentrismo centra todo juicio ético en los intereses humanos, el biocentrismo sitúa su fundamento en el valor de la vida, partiendo de dos principios básicos: por un lado, el de la consideración moral, de acuerdo con el cual las cosas vivas merecen el interés y la consideración de todos los agentes morales, simplemente en virtud de ser miembros de la comunidad de vida de la Tierra. Por otro, el del valor intrínseco, que establece que si un ser es miembro de la comunidad de vida de la Tierra, la realización de su bienestar es algo intrínsecamente valioso y, por lo tanto, merece prima facie que se le conserve o promueva como un fin en sí mismo. A partir de esos principios la Ecología Profunda exalta la naturaleza salvaje, intocada por el ser humano, como ideal al que tender, y enfoca su crítica hacia el rechazo de la vigente idea de progreso. Su praxis política se centra en tratar de evitar la intromisión humana en los ecosistemas salvajes como forma de preservación.

Ciertamente, el camino hacia el diseño de una sociedad sustentable debe partir de una revisión crítica del principio antropocéntrico, reivindicando una dimensión de la naturaleza que no sea reductible a ningún cálculo utilitario. Es decir, reconocer que la naturaleza tiene un valor intrínseco, independientemente de cualquier valor que los seres humanos le asignemos. Sin embargo, la aplicación de la ética biocéntrica por los seguidores de la Ecología profunda presenta importantes deficiencias. No cabe duda de que sus planteamientos han sido útiles para el desarrollo de determinadas concepciones, como el movimiento animalista ${ }^{5}$ o la crítica al progreso tecnológico, pero se han

\footnotetext{
${ }^{3}$ Vid., entre otros, PASSMORE, J., La responsabilidad del hombre frente a la naturaleza, Alianza editorial, Madrid, 1978.

${ }^{4}$ La corriente de la Ecología profunda se inició en 1972 por Arne NAESS, profesor de la Universidad de Oslo, quien introdujo por primera vez el término en la literatura medioambiental para diferenciarla de otras corrientes ambientalistas que empezaban a surgir en aquellos años. Dentro del activismo ecologista, la Ecología profunda es reivindicada principalmente por la organización Earth first!, que cuenta con numerosos seguidores sobre todo en Norteamérica.

${ }^{5}$ Una consecuencia dramática de la ética antropocéntrica es el dominio absoluto que la especie humana ejerce sobre el resto de los animales, que a menudo adquiere la dimensión de exterminio. Se niega así que esos animales tengan derechos de ningún tipo, reduciéndolos al estatus de cosas, olvidando su naturaleza de seres sensibles (obviando sobre todo su capacidad de sentir dolor). La ética biocéntrica, que valora la vida en cuanto tal, sea o no humana, se ha convertido en el corpus teórico de muchos de los movimientos por la liberación animal y los derechos de los animales no humanos.
} 
mostrado poco útiles al abordar la construcción de una sociedad sostenible a todos los niveles. De hecho, la Ecología profunda ha sido sometida a severas críticas.

R. GUHA, en su ya célebre artículo dentro de la literatura ecológica "El ambientalismo estadounidense y la preservación de la naturaleza: una crítica tercermundista", denuncia las consecuencias sociales que ese tipo de ideas ambientalistas, plasmadas en la política de parques naturales surgida en Estados Unidos, tiene para los países del Sur. GUHA señala que la política propuesta por la Ecología profunda es singularmente estadoundense, advirtiendo del error que supone exportar sus objetivos sociales y políticos a otros contextos diferentes ${ }^{7}$.

Las dificultades que la ética biocéntrica plantea a la hora de expresar una praxis política sustentable (no sólo ambiental, sino también socialmente), parten de que su cosmovisión, tal y como ocurre con el antropocentrismo, no deja de ser fragmentaria. Abordar los problemas ambientales olvidando los sociales es tan equivocado como lo contrario, ya que un sistema sostenible no debe serlo sólo para los "ecosistemas salvajes", sino desde luego, también para los seres humanos.

Tratando de superar esas carencias y aportar una visión holística de la realidad, la Ecología social rechaza los conceptos de antropocentrismo y biocentrismo, prefiriendo hablar de complementariedad o de integridad. La razón es que tanto la biocentricidad como la antropocentricidad (y cualquiera otras "centricidades") descansan sobre la noción de otredad y en las diferenciaciones que ésta supone. Estos conceptos parecen oponer de alguna forma lo humano y lo no humano, lo no natural y lo natural, ya sea para anteponer lo primero sobre lo segundo (antropocentrismo) o al contrario (biocentrismo). La ecología social niega esta confrontación, y rechaza considerar lo humano (política, sociedad, etc.) como algo distinto a lo natural ${ }^{8}$. Por ello habla de complementariedad, que es un principio básico de todo ecosistema: cada elemento depende de los demás, integrándose mutuamente. La realidad aparece como un proceso atravesado por relaciones retroalimentativas entre todos sus elementos. Es por esto que lo humano y lo no humano no son conceptos contrapuestos, sino complementarios. El ecosistema característicamente humano es la sociedad, que no se da en esas características en el resto de la naturaleza, y que los ecologistas sociales definen como segunda naturaleza (en la que se incluyen las estructuras políticas, sociales,

\footnotetext{
${ }^{6}$ Publicado originalmente en Enviromental Ethics, vol. 11, primavera 1989, pp. 71-93, aunque su traducción al Castellano puede hallarse en Ecología Política, No. 14, 1997, pp. 33-46. Otra dura crítica a la Ecología Profunda puede encontrarse en el extenso prólogo a la edición de 1991 de BOOKCHIN, M., La ecología de la libertad. La emergencia y la disolución de las jerarquías, publicado en España por Nossa y Jara (col. Madre Tierra), 1999.

${ }^{7}$ Autor indio, cita el ejemplo del Proyecto Tigre desarrollado en su país. Se trata de una red de parques naturales, celebrada por la comunidad conservacionista internacional como un éxito destacado que ha colocado los intereses de los tigres contra los de los campesinos pobres que viven dentro y alrededor de la reserva. Indica cómo la demarcación de reservas para los tigres fue posible sólo mediante el desplazamiento físico de las aldeas existentes y de sus habitantes, y cómo su manejo requiere la exclusión continua de campesinos y ganado. GUHA, R., "El ambientalismo estadounidense y la preservación...", en Ecología Política No14, 1997, p. 36.

${ }^{8}$ Conscientes del error que supone esta confrontación radical, pero partiendo de la afirmación de que hablar de política supone de por sí una cierta perspectiva antropocéntrica, algunos autores, como GORDILLO FERRÉ (véase "Del Derecho ambiental...", op. cit., pp. 330 y ss.), hablan de un "antropocentrismo débil" como propuesta ética que sustituya al antropocentrismo fuerte o estricto. Sin embargo, su propuesta no abandona el principio excluyente de "otredad" que aquí cuestionamos.
} 
económicas, etc.), mientras que la primera naturaleza está integrada por todos aquellos ecosistemas no exclusivamente humanos. El hecho de hablar de primera y segunda naturaleza no supone priorizar una sobre otra ni oponer ambas, sino que hace referencia simplemente a su anterior o posterior surgimiento en la Historia del planeta. De todo ello parte una propuesta ética basada en la complementariedad y el apoyo mutuo, que conlleva una mirada reconstructiva a partir de un concepto participativo de otredad, que enfatiza la variedad sin estructurar diferencias en un orden jerárquico, y donde participación y diferenciación son conceptos que le dan significado?

Además de ser éticamente satisfactoria y coherente desde la dinámica ecosistémica, esta concepción es muy útil y operativa en el análisis ecopolítico. Por un lado, porque demuestra la interconexión entre todos los elementos de la naturaleza, entre ellos la sociedad humana, lo que impide que la política se desarrolle de espaldas a la ecología. Pero por otra parte, supone no olvidar que cualquier propuesta de preservación ambiental debe contar con la realidad de las estructuras político-sociales. En realidad, hablar de ecología política es tratar la relación de la sociedad humana estructurada políticamente con la naturaleza, lo que implica introducir en el análisis un componente humano importante (ciertamente, estamos buscando cómo estructurar la sociedad humana, no el resto de la naturaleza, que se rige por sus propias leyes).

\section{Una reflexión sobre la sustentabilidad}

Toda teoría ecopolítica tiene como objetivo la formulación de una sociedad sustentable, es decir, una sociedad que permita un desarrollo sostenible. Sin embargo, la sustentabilidad (o sostenibilidad) no es un término unívoco, sino que hoy día es empleado con sentidos muy distintos. Es conveniente precisar algo más este concepto, que en los últimos tiempos ha sido privado de su sentido original.

Los antecedentes del término hay que buscarlos en el primer informe del Club de Roma Los límites del crecimiento, de 1972. En el mismo se ponía en cuestión por primera vez por "economistas reconocidos" la viabilidad del crecimiento continuo como objetivo económico planetario. Años después, Ignacy SACHS acuñó el término ecodesarrollo, como modelo de desarrollo socialmente justo, ecológicamente compatible y económicamente viable. Sin embargo, este término fue vetado por Henry Kissinger para ser usado en los documentos de Naciones Unidas, y fue sustituido por el de desarrollo sostenible. Este cambio era indicador de lo que ocurriría años después, al aproximarse al concepto de desarrollo autosustentable, manejado desde hacía años por los economistas, y que se identificaba con crecimiento económico.

El significado original de desarrollo sostenible, reflejado mejor por el término ecodesarrollo, y empleado por los ecologistas desde inicios de los años ochenta, puede enunciarse como aquel desarrollo que permite satisfacer nuestras necesidades actuales sin comprometer la capacidad de las generaciones futuras para satisfacer las suyas.

\footnotetext{
${ }^{9}$ Dentro de la Ecología Social el referente básico lo sigue siendo la obra de BOOKCHIN, M., $L a$ ecología de la libertad. La emergencia y la disolución de las jerarquías, Nossa y Jara (col. Madre Tierra), Madrid, 1999. Sin olvidar las aportaciones de otros/as autores/as como Janet BIEHL, o, en el ámbito Latinoaamericano, Eduardo GUDYNAS.
} 
El concepto se puso en boga a partir de la definición del mismo presentada en el informe Nuestro futuro común, elaborado por la Comisión Mundial del Medio Ambiente y Desarrollo en 1987, organismo liderado por la noruega Gro Harlem Brundtland (el informe es más conocido como Informe Brundtland). Aunque en él se acogía la acepción manejada desde hacía años atrás por el ecologismo, se introducía un importante matiz, al ligar el desarrollo sostenible de forma expresa con el desarrollo económico.

El informe decía: "Está en manos de la humanidad hacer que el desarrollo sea sostenible, es decir, asegurar que satisfaga las necesidades del presente sin comprometer la capacidad de las futuras generaciones para satisfacer las propias. El concepto de desarrollo sostenible implica límites - no límites absolutos, sino limitaciones que imponen a los recursos del medio ambiente el estado actual de la tecnología y de la organización social y la capacidad de la biosfera de absorber los efectos de las actividades humanas-, pero tanto la tecnología como la organización social pueden ser ordenadas y mejoradas de manera que abran el camino a una nueva era de crecimiento económico" (cursiva propia).

Como indica GUDYNAS, ello explica el gran éxito y amplia aceptación de este informe: "para aquellos verdaderamente preocupados por un nuevo desarrollo alternativo, la primera parte de la definición era alentadora, y para otros, todavía obsesionados con el crecimiento económico, la última parte les daba un respiro" ${ }^{\text {. }}$.

El resultado ha sido una total perversión del sentido original del término, que ha pasado a describirse en los años 90 como aquel desarrollo que mejora la calidad de la vida humana sin rebasar la capacidad de carga de los ecosistemas que la sustentan, principio inspirador de las actuales políticas ambientales, y en mi opinión totalmente insuficiente para lograr una auténtica sostenibilidad ${ }^{11}$. Esta alteración de significado supone una lectura de la crisis ecológica que no centra el debate en el sentido y la necesidad del progreso (que es entendido sólo como crecimiento). Desde este punto de vista, el problema se centra en algunos desajustes técnicos, solucionables con mejoras en las técnicas de producción, con nuevas investigaciones, que solucionen esos fallos sin frenar el camino del progreso. Sin embargo, podemos decir con RIECHMANN que "de poco o nada servirán las reformas para ecologizar la producción, y muy particularmente las mejoras en eficiencia, si no se frena el crecimiento material en nuestras sociedades sobredesarrolladas".

Por ejemplo, de nada sirve mejorar la eficiencia energética o el ahorro de materiales un $1 \%$ o un $2 \%$ anual, si el objetivo económico sigue siendo crecer un 3 ó $4 \%$ anual. O, más concretamente, de nada servirá reducir a la mitad las emisiones contaminantes de cada automóvil individual si al mismo tiempo se duplica la distancia

\footnotetext{
${ }^{10}$ GUDYNAS, E., "La privatización de la vida: América Latina ante las nuevas políticas ambientales neoliberales", en www.dei-cr.org/Anteriores/81/pasos81_1.html. Primera versión publicada en la revista Multiversidad, Montevideo (Uruguay).

${ }^{11}$ Buena muestra de ello es la respuesta oficial del Gobierno británico a la publicación del informe Brutland, expresando su total apoyo al desarrollo sostenible, para afirmar a continuación que eso es precisamente lo que estaba llevando a cabo el thatcherismo. Se trata del informe titulado Blueprint for a Green Economy, elaborado en 1989 a instancias del Ministerio de Medio Ambiente del Gobierno de Margaret Teahcher, que alcanzaría gran éxito en el ámbito anglosajón, y que ha inspirado en buena medida las políticas ambientales adoptadas más tarde.
} 
total recorrida por estos vehículos, tal y como sucedió en Estados Unidos entre 1965 y $1990^{12}$.

El sistema económico y político se ha apropiado del concepto de sustentabilidad, permitiendo que el paradigma desarrollista presente desde la Revolución industrial quede intacto. Este hecho ha llevado incluso a que muchos ecologistas rechacen actualmente la utilización del término "desarrollo sostenible", por lo ambiguo y engañoso que puede resultar.

Sin embargo, los datos empíricos demuestran que existe una capacidad límite de sustentación para el planeta, y que nos estamos acercando a ella aceleradamente. Teniendo en cuenta que la población mundial crece rápidamente, y que el nivel de consumo de un sector de la misma lo hace aún más deprisa, se estima que a este ritmo la capacidad máxima de sustentación del planeta se alcanzará tan sólo en una generación aproximadamente.

Ante esta situación, tal y como advierte RIECHMANN, una auténtica sustentabilidad supone necesariamente minimizar el nivel de entropia ${ }^{13}$. Esto implica tanto respetar los límites (de lo que tomamos de la biosfera, y de lo que devolvemos a ella en forma de residuos) como pensar en el mañana (en las generaciones futuras) ${ }^{14}$. Ante todo, romper con el paradigma desarrollista que vivimos desde hace dos siglos, y que nos ha colocado en la actual situación de degradación ecológica.

Un elemento central de esa ruptura es el de ser conscientes de la dimensión espacio-temporal de nuestras decisiones políticas, entender que éstas no sólo despliegan sus efectos en el lugar y el momento en que son adoptadas, sino que pueden incidir más

12 RIECHMANN, J., "Desarrollo sostenible: la lucha por la interpretación”, en VV.AA., De la economía a la ecología, Editorial Trotta y Fundación $1^{\circ}$ de Mayo, Madrid, 1995, p. 13.

${ }^{13}$ Desde la enunciación de las dos Leyes de la Termodinámica en el siglo XIX, el estudio de los flujos de energía en los ecosistemas ha sido uno de los instrumentos analíticos por excelencia de la Ecología, pero no menos importante ha sido su aplicación a ciencias sociales como la Economía. La primera Ley de la Termodinámica o Ley de conservación de la energía, enunciada por Joule y Maner entre 1840 y 1842, dice que la energía (o la energía-materia) no se crea ni se destruye, sólo se transforma de unas formas a otras. Nótese que de tal formulación podría deducirse que todas las preocupaciones ecológicas se desvanecen, pues parece dar cuerpo a las teorías económicas clásicas que sostenían la inagotabilidad de los recursos naturales (pues, siendo así, al utilizarlos éstos no desaparecerían, sino que sólo se transformarían en otros diferentes). Sin embargo, esa afirmación no es cierta, dado que todos los tipos de energía no son igualmente convertibles en trabajo útil. P uede decirse que existe energía "buena" y "mala" para nosotros, los seres vivos. De ahí parte la segunda ley de la termodinámica, enunciada poco después por Clausius y Thompson: en un sistema cerrado todos los procesos físicos, naturales y tecnológicos ocurren de tal manera que la disponibilidad de la energía implicada decrece. La síntesis de ambos principios dice por tanto que la cantidad de energía permanece constante (primera ley); pero su calidad se degrada constantemente (segunda ley). Y existe además una formulación del segundo principio no inmediatamente equivalente a los anteriores, que dice que: en los procesos espontáneos que ocurren dentro de sistemas cerrados, las concentraciones (de materia, de energía o cualquier otra entidad) tienden a disiparse, la estructura tiende a degradarse y desaparecer, el orden se convierte en desorden. Esta segunda formulación se relaciona con las anteriores por medio del concepto de entropía, que es, por decirlo así, "la medida del desorden" del mundo físico; así alta entropía significa desorden, y baja entropía significa orden. La vida, para poder desarrollarse, exige un nivel entrópico bajo, porque de hecho, los seres vivos somos entidades con niveles muy bajos de entropía.

${ }^{14}$ Más ampliamente, vid. RIECHMANN, J. y FERNÁNDEZ BUEY, F., Ni tribunos. Ideas y materiales para un programa ecosocialista, Siglo XXI, Madrid, 1996, pp. 336 y ss. 
allá de esos límites. La dimensión espacial de las decisiones políticas ha quedado de manifiesto a partir de los datos aportados por la Ecología, que demuestran el carácter global de todo problema ambiental (por ejemplo, la destrucción de la capa de ozono se manifiesta con más crudeza precisamente en lugares donde las emisiones de gases son menores, como el Antártida). Al mismo tiempo, esta dimensión espacial, en conexión con la actual situación económica mundial, nos obliga a analizar nuestras pautas de vida a la luz del principio de universalidad. Existen niveles de consumo a los que sólo un determinado sector de la población mundial puede acceder, ya que su generalización acabaría con la capacidad de sustentación del planeta. Este hecho debe conducirnos a rechazar aquellas pautas de consumo antisociales, es decir, no universalizables. Lo cual supone discernir entre cuáles son nuestras necesidades básicas, no básicas y deseos socialmente legítimos ${ }^{15}$.

Por otro lado, ser conscientes de la dimensión cronológica de la política supone entender que cualquier actor sólo puede actuar en cuanto que otros "no le hayan quitado antes el espacio de actuación a través de una extensión excesiva del suyo" " Garrido Peña habla de cronopolítica para denunciar la concepción atemporal de la forma de política contemporánea (Estado y Capital), la cual se comporta como si no hubiera tiempo, sobre la ilusión de un tiempo eterno, a través de una idea de progreso que no es sino el trasunto secularizado de la eternidad. Frente a ello, la cronopolítica supone interiorizar las enseñanzas de la segunda ley de la termodinámica, del hallazgo de la entropía, como base sobre la que desacelerar el tiempo social, lograr desacelerar la Historia ${ }^{17}$.

Cediendo de nuevo la palabra a RIECHMANN, los criterios operativos para un verdadero desarrollo sostenible podrían ser los siguientes:

\section{Principio de irreversibilidad cero: reducir a cero las intervenciones acumulativas y los daños irreversibles}

2. Principio de recolección sostenible: las tasas de recolección de los recursos no renovables deben ser iguales a las tasas de generación de estos recursos.

3 Principio del vaciado sostenible: es cuasi-sostenible la explotación de recursos naturales no renovables cuando su tasa de vaciado sea igual a la tasa de creación de sustitutos renovables.

\section{Principio de emisión sostenible: las tasas de emisión de residuos deben ser iguales a las capacidades naturales de asimilación de los ecosistemas a los que se emiten esos residuos (lo cual implica emisión cero de residuos no biodegradables).}

${ }^{15}$ El concepto de "consumo antisocial" se aproxima al de "valor de uso anticomunista" de W. HARICH, que es aquel valor de uso que en ninguna circunstancia social, cualquiera que ésta fuera, podría ser consumido por todos los miembros de la sociedad sin excepción. RIECHMANN, J., "Desarrollo sostenible: la lucha por la interpretación", op. cit., pp. 16 y 17.

${ }^{16}$ VICENTE GIMÉNEZ, T., “Orden ambiental-orden jurídico. Interdependencia, participación y condicionalidad”, en VICENTE GIMÉNEZ (coord.), Justicia ecológica y protección del medio ambiente, Trotta, Madrid, 2002, p. 55.

${ }^{17}$ La cronopolítica es una política del tiempo, "es una política de los límites, del crecimiento sostenido (...) que no pretende colonizar-maquinizar la espontaneiedad misteriosa y libre de lo social, sino equilibrar el grado de entropía que esta espontaneidad genera, para que pueda seguir subsistiendo sobre el vértice de la crisis". GARRIDO PEÑA, F., "La Ecología como política", en GARRIDO PEÑA (comp.), Introducción a la Ecología política, Comares, 1993, pp. 10 y ss. Más ampliamente, véase la obra del mismo autor La ecología política como política del tiempo, Comares, Granada, 1996. 
5. Principio de selección sostenible de tecnologías: han de favorecerse las tecnologías que aumenten la productividad de los recursos (el volumen de valor extraído por unidad de recurso) frente a las tecnologías que incrementen la cantidad extraída de recursos (eficiencia frente a crecimiento).

6. Principio de precaución: ante la magnitud de los riesgos a que nos enfrentamos, se impone una actividad de vigilante anticipación que identifique y descarte de entrada las vías que podrían llevar a desenlaces catastróficos, aún cuando la probabilidad de éstos parezca pequeña y las vías alternativas más difíciles u onerosas ${ }^{18}$.

\section{PROTECCIÓN JURÍDICA DEL AMBIENTE EN EL ESTADO DE DERECHO}

Como bien expresa la distinción entre primera y segunda naturaleza, el ambiente es una realidad anterior a cualquier estructura de creación humana, entre ellas el Derecho y el Estado. La inherencia del ser humano a la naturaleza hace que ésta preceda a cualquier regulación positiva, es más, le hace ser requisito sine qua non para el reconocimiento de cualquier derecho a la persona. Partiendo de esta evidencia, es posible contemplar el Derecho desde una perspectiva ecológica, desde la cosmovisión holística que enfatiza la integración e interconexión del sistema humano con el resto de ecosistemas.

En este contexto, el ecosistema humano presenta innegables peculiaridades, centradas en la existencia de una avanzada y compleja estructura social. En consonancia con TÖNIES ${ }^{19}$, se puede afirmar que dentro de ese peculiar entorno el Derecho aparece como un mecanismo de regulación del ecosistema, como medio de autorregulación, expresión de un principio tan básico en el proceso natural como es el de la capacidad de adaptación de la especie. Consecuencia de la ausencia en el ser humano de mecanismos que inhiben la violencia intraespecífica, a diferencia del resto de especies animales, el Derecho aparece originariamente como un inhibidor de la agresividad dentro del grupo, posibilitando la convivencia dentro del ecosistema humano ${ }^{20}$.

Sin embargo, llegados a un punto en que es evidente que esa adaptación no se ha producido, sino que se ha puesto en peligro la normalidad natural, el Derecho adquiere un nuevo papel: el de intervenir activamente en nuestra ecología afectada, tratando de restaurar el equilibrio. A continuación analizaremos algunos aspectos de la intervención del Derecho en el intento de evitar esa ruptura de la normalidad natural, así como algunas cuestiones sobre la idoneidad de las actuales estructuras político-jurídicas para edificar una sociedad sustentable.

\footnotetext{
${ }^{18}$ RIECHMANN, J., "Desarrollo sostenible: la lucha por la interpretación”, op. cit., p. 27.

${ }^{19}$ TÖNIES realiza un análisis ecológico del Derecho desde la teoría de sistemas en Ist Das Recht Ein Biotop?, Berlín, 1987. Expuesto por VICENTE JIMÉNEZ, T., en “Orden ambiental-orden jurídico...", op. cit., pp. 47 y ss.

${ }^{20}$ La rápida evolución cultural de la especie humana podría ser la causa que no ha posibilitado el desarrollo de inhibiciones capaces de frenar de forma innata nuestros impulsos agresivos intraespecíficos. El Derecho aparece así como un instrumento inhibidor de la agresividad social. Véase ROCAMORA GARCÍA-VALLS, P., Agresividad y Derecho, Bosch, Barcelona, 1990.
} 


\section{Breve descripción de la política ambiental en el Estado español}

Como decíamos, la toma de conciencia a cerca de los problemas ecológicos hizo reaccionar a la comunidad internacional sobre la necesidad de otorgar una cierta protección al ambiente en el plano jurídico. Esa inquietud cristalizó en la adopción de la Declaración de Estocolmo, en el seno de la Convención de Naciones Unidas sobre el medio humano de 1972, cuyo Primer principio afirma:

"El hombre tiene el derecho fundamental a al libertad, a la igualdad y al disfrute de condiciones de vida adecuadas en un medio de calidad tal que le permita llevar una vida digna y gozar de bienestar y tiene la solemne obligación de proteger y mejorar el medio para las generaciones presentes y futuras".

Se trata del primer reconocimiento internacional del derecho humano a un ambiente adecuado. Posteriormente muchos otros textos internacionales se han expresado en términos similares ${ }^{21}$, entre los cuales cabe destacar la Declaración de Río de 1992:

"Los seres humanos constituyen el centro de las preocupaciones relacionadas con el desarrollo sostenible. Tienen derecho a una vida saludable y productiva en armonía con la naturaleza."

Dentro de la teoría de los Derechos Humanos, el derecho a un ambiente adecuado se situaría dentro de los llamados "derechos de tercera generación", cuyo valor guía vendría definido por la solidaridad, frente al valor libertad que sirvió de guía para la primera generación de derechos, y el valor igualdad que fundamentó la segunda ${ }^{22}$. Esta tercera generación de derechos, y en especial el derecho a un ambiente adecuado, se caracterizan además por la relevancia de las futuras generaciones como sujeto de los mismos. La doctrina ha puesto de manifiesto los problemas que tal reconocimiento supone desde las actuales categorías dogmáticas, pues en definitiva se trata de atribuir derechos a un sujeto colectivo inexistente que, estrictamente, no tiene si quiera un derecho a existir (la existencia es un requisito previo para la atribución de derechos, y podríamos decir que un ambiente adecuado es el requisito previo para posibilitar la existencia).

En cualquier caso, este reconocimiento a nivel supranacional ha tenido reflejo en los ordenamientos nacionales, a través de la incorporación del derecho a un ambiente adecuado en sus marcos constitucionales, y la aprobación de una abundante y especializada legislación en materia ambiental. Centrándonos en la situación del Estado español, si bien el desarrollo ha sido bastante similar en todos los Estados occidentales, el marco jurídico de protección ambiental está contenido en el art. 45 de la Constitución. La inclusión de este artículo en 1978 ha supuesto un hito en la Historia jurídica española

${ }^{21}$ El derecho a un medio ambiente adecuado está reconocido en la Carta Africana de los Derechos Humanos y de los Pueblos de 1981, así como en el Protocolo adicional al Convenio Americano sobre derechos humanos de 1969. Sin embargo, no fructificó el intento de introducir un protocolo que lo reconociese en la Convención Europea de Derechos Humanos de 1950.

${ }^{22}$ Si la primera generación de Derechos Humanos está compuesta por los derechos de defensa de las libertades de los individuos y la segunda por los llamados "derechos de participación", la tercera generación es una "respuesta a la degradación de los derechos fundamentales ante las nuevas tecnologías, los conflictos armados, o la división Norte-Sur, y representan o reivindican un nuevo orden social para los Estados y la comunidad internacional en su conjunto". VICENTE GIMÉNEZ, T., "Proyección de la justicia ecológica en la ordenación política y jurídica del medio ambiente", en VICENTE GIMÉNEZ (coord), Justicia ecológica ..., op. cit., p. 76. 
y ha sido el sustento de la transformación en la política ambiental de los últimos veinte $\operatorname{años}^{23}$. Dicho artículo reconoce el derecho de todos "a disfrutar de un medio ambiente adecuado para el desarrollo de la persona, así como el deber de conservarlo". Y además, impone a los poderes públicos el deber de velar por su protección, "apoyándose en la indispensable solidaridad colectiva".

Como ha advertido un sector de la doctrina, el primer comentario que cabe hacer al precepto es de tipo sistemático. Llama la atención que dicho artículo no se ubique dentro de los derechos fundamentales reconocidos por la Constitución, sino que se incluya dentro de los principios rectores de la política social y económica-que según el art. 53.3 deben informar toda la legislación positiva-. Sin duda, esta concepción jurídica del derecho a un medio ambiente adecuado como "principio rector" de la ordenación económica, y no como auténtico derecho fundamental, es determinante para las conclusiones extraídas por el Tribunal Constitucional en esta materia, y en general para todo el enfoque jurídico positivo de la protección ambiental en el vigente ordenamiento.

En cuanto a su contenido, LOPERENA ROTA señala que el es el uso de los bienes ambientales el que configura el núcleo esencial del derecho reconocido en el art. $45 \mathrm{CE}$. El objetivo esencial del precepto sería entonces que los derechos de propiedad o de otra clase que puedan ostentarse sobre bienes ambientalmente trascendentes estén excluidos de actuaciones que puedan alterar las condiciones fundamentales de la biosfera, de modo que no puedan ser utilizados de forma contraria al interés general. El concepto de "ambiente adecuado" remite en último término a los parámetros biosféricos determinados por la ciencia, de forma que el derecho del art. 45.1 es en definitiva un derecho de configuración legal, conforme al art. 53.3 $\mathrm{CE}^{24}$.

\footnotetext{
${ }^{23}$ El único precedente constitucional de la protección del ambiente en España lo encontramos en la Constitución de la Segunda República de 1931, cuyo art. 45.2 prescribía "la protección por parte del Estado de los lugares notables por su belleza natural". Aunque realmente, este artículo está lejos de reconocer un derecho al medio ambiente, otorgando más bien cierta protección al valor "paisaje" (que no es sino la percepción subjetiva del entorno por el ser humano). Obviamente, los problemas ecológicos no eran en aquel momento lo suficientemente explícitos como para otorgar una protección más intensa.

Por otro lado, la Constitución de 1978 sí ha supuesto una verdadera transformación en la política ambiental, al inspirar un intensa labor legislativa y administrativa en esta materia. En primer lugar, a través de la creación de diversos organismos dirigidos a la protección ambiental. Mientras que inicialmente este tipo de competencias no era atribuida a ningún órgano específico, sino que eran ejercitadas por diversos entes con competencia sectorial, poco a poco se fue caminando hacia una progresiva especialización. Los primeros pasos se dieron en los años ochenta, creando en el seno del Ministerio de Obras Públicas una Dirección General de Medio Ambiente, con eficacia horizontal, para intervenir también en los demás Ministerios. Posteriormente, dicha Dirección General pasaría a ser Subsecretaría, y en 1991 a Secretaría de Estado. En 1993, el Ministerio de Obras Públicas incluyó en su denominación la expresión "y Medio Ambiente" (cambiando su nombre por el de MOPMA), y el paso definitivo hasta el momento se produjo en 1996, con la creación del Ministerio de Medio Ambiente. Del mismo modo, se han creado numerosos organismos autónomos y entidades públicas empresariales con tareas específicas en materia ambiental, a lo que hay que unir las instituciones autonómicas -Consejerías de Medio Ambiente y administración instrumental propia-, fruto de la asunción por éstas de competencias ambientales. Paralelamente, el número de normas legales y reglamentarias, estatales y autonómicas, destinadas a la protección del medio se ha multiplicado, junto con el avance de la ordenación comunitaria en este terreno.

${ }^{24}$ Véase LOPERENA ROTA, D., Los principios del Derecho ambiental, Civitas, Madrid, 1998.
} 
Por otro lado, y atendiendo al tenor literal del precepto, puede apreciarse que axiológicamente en él se hace referencia al medio ambiente en un sentido muy particular, asignándole un valor calificado de adecuado para el desarrollo de la persona, expresión que, como bien indica VICENTE GIMÉNEZ, encuentra su expresión más precisa en el concepto de calidad de vida (que según el art. 45.2 CE, hace referencia a que la evolución ha de tender a la satisfacción de las necesidades básicas para el desarrollo del hombre y la posibilidad de su existencia). Por lo tanto, partiendo del marco constitucional, el fin que perseguiría el Derecho en materia ambiental sería el de conservar y mejorar el medio ambiente con el estricto objetivo de alcanzar metas exclusivamente antropocéntricas ${ }^{25}$ : el mantenimiento y mejora de la calidad de vida humana.

La ubicación sistemática del artículo, su configuración subordinada al desarrollo normativo posterior, y las limitaciones derivadas de la redacción del art. 45, han llevado a la afirmación, en mi opinión acertada, por un sector de la doctrina de que la Constitución de 1978 no reconoce un verdadero derecho humano al medio ambiente, en sí mismo considerado.

A partir de esta configuración constitucional, debemos hacer referencia a otro factor que influye decisivamente en la orientación de la protección ambiental en el ordenamiento vigente, como es el propio concepto de ambiente manejado en el mismo. $\mathrm{Y}$ éste es un aspecto que se ha convertido en uno de los elementos de debate característicos entre los juristas ambientalistas. Básicamente, pueden distinguirse en la doctrina dos posturas enfrentadas: aquellos que defienden un concepto restrictivo de ambiente, y quienes propugnan un concepto amplio del mismo.

El principal defensor de la utilización de un concepto restrictivo de ambiente ha sido MARTÍN MATEO, autor considerado como uno de los pioneros del ambientalismo jurídico español ${ }^{26}$. En su opinión, el concepto jurídico de ambiente no se corresponde con "naturaleza", sino sólo con "una parte de la naturaleza" concreta: los elementos de ésta de carácter dinámico que han sido considerados en nuestra tradición jurídico-política como res nullius, y que posteriormente han pasado a integrar el dominio público. La necesidad de protección vendría del incremento en la intensidad de su aprovechamiento que, fruto de la civilización industrial y urbana, se ha producido en las últimas décadas, y que amenazan las condiciones necesarias para su aprovechamiento colectivo. Según este autor, manejar un concepto más amplio de ambiente sólo dificultaría la intervención del Derecho en este ámbito.

A la vista de la jurisprudencia constitucional, parece que la aportación de este autor a la doctrina de la protección jurídica del ambiente ha sido determinante, pues ambos caminan en una misma dirección. La doctrina fundamental del Tribunal Constitucional en este asunto se encuentra recogida en su Sentencia núm. 64/1982. En ella, el Tribunal afirma que el art. $45 \mathrm{CE}$ impone que "el objetivo de la política económica no puede ser en ningún caso la explotación al máximo de los recursos naturales y el aumento de la producción a toda costa; por el contrario, la utilización racional de esos recursos debe armonizarse con la protección de la naturaleza, con lo que llega a la conclusión de que

\footnotetext{
${ }^{25}$ VICENTE GIMÉNEZ, T., "Proyección de la justicia ecológica...", op. cit., p. 77.

${ }^{26}$ Entre su bibliografía cabe destacar su Tratado de Derecho ambiental, Trivium, Madrid, $1991\left(1^{\text {a }}\right.$ edición).
} 
el legislador debe compaginar la protección de dos bienes constitucionales en conflicto: el medio ambiente y el desarrollo económico"27.

Los proyectos de MARTÍN MATEO y del Tribunal Constitucional parecen coincidir; para ambos existe una tensión dentro del ordenamiento jurídico entre normas ambientales y no ambientales, que pueden perseguir finalidades diversas, e incluso antitéticas. Y para ambos, el centro de la problemática ambiental se encuentra en la protección de los bienes comunes, como el aire y el agua, a través del control de la contaminación. Como indica GORDILLO FERRÉ, este proyecto podría calificarse de capitalismo verde $^{28}$. Es decir, se trataría de transformar el capitalismo de mercado en un ecocapitalismo, introduciendo ciertas medidas correctoras a través de normas jurídicas de protección ambiental, con el fin de preservar lo que para Martín Mateo debe ser el objeto del Derecho ambiental: los bienes de aprovechamiento común, esencialmente el aire y el agua. Y ciertamente, éste parece ser el espíritu de la propia Constitución, al incluir el art. 33 y 38 (derecho a la propiedad privada y libertad de empresa, respectivamente) dentro del Capítulo II del Título I CE ("De los derechos y deberes de los ciudadanos"), e incardinar el art. 45 (derecho a un medio ambiente adecuado) dentro de su Capítulo III, como principio rector que debe "informar" o limitar los derechos anteriores. Es decir, que el modelo de economía mixta diseñado por la Constitución no deja de ser en esencia un sistema económico de mercado, al cual se introducen distintas correcciones para alcanzar ciertos fines sociales, y en este caso, también ambientales. Estas medidas correctoras se plasman en la instauración del principio "quien contamina paga", técnicas de policía ambiental, mecanismos coercitivos, medidas de fomento de determinadas conductas, etc.

Por último, descendiendo a un plano menos abstracto como es la legislación ordinaria con finalidad ambiental, se puede apreciar cómo tanto en el ordenamiento estatal como en los autonómicos ésta forma un cuerpo normativo vinculado esencialmente al Derecho público, y concretamente al Derecho administrativo. Hasta el punto de que se habla ya de un "Derecho ambiental", como una especialidad del Derecho administrativo. Quizá, la causa de esta vinculación al Derecho administrativo haya que buscarla en la asignación por parte de la Constitución de la tarea de preservar el medio a los poderes públicos ${ }^{29}$. Aunque, obviamente, también existan normas dirigidas a la preservación ambiental en otras ramas del ordenamiento, como en el articulado del Código penal (arts. 325 y ss., por imperativo del propio art. $45.3 \mathrm{CE}$ ), teniendo en cuenta además que las agresiones ambientales darán lugar a menudo a responsabilidad entre particulares.

En resumen, podemos decir que la protección jurídica del ambiente en el actual Ordenamiento español se caracteriza por: no considerar el derecho a un medio ambiente adecuado como un auténtico derecho fundamental; creación de una nueva "rama" dentro del Derecho administrativo en la cual se incardina el grueso de las normas de protección ambiental; utilización de un concepto de ambiente muy restrictivo; e instrumentación de medidas correctoras en el sistema económico de mercado (esencialmente en los sistemas de producción).

\footnotetext{
${ }^{27}$ RTC $1982 \backslash 64$.

${ }^{28}$ GORDILlO FERRÉ, J.L., "Del Derecho ambiental a la ecologización del Derecho”, op. cit., p. 322.

${ }^{29}$ Ibidem, p. 311.
} 


\section{Críticas y alternativas a la actual política ambiental}

A la vista de la evolución que el deterioro ambiental ha experimentado durante los últimos años, parece que el proyecto del capitalismo verde, que es la tónica dominante en todos los Estados económicamente desarrollados, no funciona. La introducción de medidas correctoras en el sistema económico -de las cuales el principio "quien contamina paga" es ejemplo paradigmático- y la implantación de instituciones dirigidas a la protección del ambiente en la Administración, no están consiguiendo reducir el ritmo frenético de destrucción ambiental, o al menos no lo están consiguiendo en la medida necesaria para evitar los resultados catastróficos que se prevén a corto y medio plazo $^{30}$. Quizá lo que ocurra es que el proyecto del ecocapitalismo no se esté llevando realmente a la práctica, pues ello requeriría un reformismo mucho más intenso que el planteado hasta ahora. Aunque en realidad, ese proyecto podría calificarse de inviable, pues las reformas necesarias para atajar la crisis a buen seguro llevarían a algo que no podría calificarse ya de capitalismo. Es muy probable que capitalismo y ecologismo sean términos antitéticos e irreconciliabes. Aunque nos ocuparemos más tarde de este asunto, baste ahora adelantar que la teoría capitalista parte de un error fundamental al reducir la naturaleza, al igual que el trabajo, a la categoría de mera mercancía, considerando los daños ambientales externalidades respecto al proceso productivo, aprehensibles monetariamente.

En cualquier caso, es necesario un análisis de las causas que hacen que el actual sistema de protección ambiental falle. Y junto con esas críticas, hay que tomar en consideración a diversos autores que han propuesto soluciones que permitirían que el Estado de Derecho fuese un modelo válido para regir una sociedad sustentable.

Una primera crítica que ha planteado tanto la doctrina como algunos grupos ecologistas es la no consideración del derecho a un medio ambiente adecuado como verdadero derecho fundamental en la Constitución. Jurídicamente, este dato tiene gran importancia, pues imposibilita la invocación directa de su ejercicio subjetivo. La respuesta que habitualmente se ha dado a esta crítica ha sido la de que, en realidad, gran parte del contenido de este derecho se encuentra ya subsumido dentro del ámbito de protección de otros derechos sí reconocidos como fundamentales, como el derecho a la salud, la intimidad o el libre desarrollo de la personalidad ${ }^{31}$. Y que aquellos contenidos no incluidos en esos derechos, gozan de un nivel de protección menor, de forma que sólo pueden ser alegados en la medida en que sean desarrollados por Ley. Como dijimos más arriba, tampoco pueden olvidarse las dificultades técnicas que supone para las

${ }^{30}$ Piénsese como ejemplo en las emisiones de $\mathrm{CO}_{2}$ a la atmósfera, cuyos límites acordados son vulnerados de forma sistemática, o burlados con mecanismos como el de la compraventa de cuotas de emisión. Cuando incluso los objetivos marcados inicialmente son muy insuficientes para evitar el desastre del cambio climático.

${ }^{31}$ Por ejemplo, en los últimos años parece haber cobrado cierta relevancia la protección del medio ambiente por la vía de la defensa del derecho a la intimidad domiciliaria. En este tema, los casos de mayor trascendencia de los que ha conocido la Comisión y el Tribunal Europeo de Derechos humanos han sido los de ciertos ruidos producidos por un aeropuerto británico, en un campo de tiro alemán, y también respecto a los olores nauseabundos provocados por una instalación depuradora de agua construida en Lorca, Murcia (el ya célebre caso López Ostra). En estos supuestos el Tribunal precisó que sólo las molestias importantes y continuas podían constituir infracción al derecho a la intimidad. PICONTÓ NOVARES, T., En las fronteras del Derecho, Dykinson, Madrid, 2000, p. 73. 
actuales estructuras jurídicas incluir dentro del catálogo de Derechos fundamentales aquellos en que, aunque titulares subjetivos lo sean sólo las personas actuales, los titulares de las obligaciones correlativas lo están también en dimensiones que tienden a proteger a las generaciones futuras.

Sin embargo, la necesidad de reconocimiento del medio ambiente adecuado como derecho fundamental no es en absoluto baladí ${ }^{32}$. Partiendo de que normas internacionales más antiguas que la Constitución hacían ya referencia a aspectos ecológicos de forma explícita, puede decirse que la norma de 1978 nace con un cierto "desfase" en esta materia, al relegar la protección del ambiente a la categoría de mero principio rector de la política económica.

$\mathrm{Su}$ reconocimiento como derecho fundamental tiene importancia elemental por razones "de enfoque". La consecuencia de una visión no fragmentaria de la realidad como la que aquí se ha defendido debe ser su consideración como auténtico derecho fundamental, y de importancia prioritaria, si tenemos en cuenta como dijimos antes que su viabilidad es requisito previo e irrenunciable para el reconocimiento de cualquier otro derecho. Supone además dar al problema la importancia que tiene, situándolo en un plano cuanto menos paralelo al desarrollo económico. Implicaría abordar el conflicto que plantea el Tribunal Constitucional (entre desarrollo económico y protección ambiental) desde otra perspectiva, en la que ambos intereses se encontraran, al menos en el punto de partida, en una posición de equilibrio. Ello puede ser además muy importante desde el punto de vista hermenéutico.

Por otro lado, es evidente que existe una estrecha interconexión entre los derechos humanos y la protección ambiental. Tal y como mantiene BIGUES, "los derechos humanos dependen de la protección ambiental y, a su vez, la protección ambiental debe basarse, para ser eficaz, en el ejercicio de los derechos humanos, como el derecho a la información, a participar, a reclamar o a recibir indemnizaciones por los daños sufridos"33. Es imprescindible poner en conexión y complementar los derechos civiles y políticos y los derechos económicos, sociales y culturales, para evitar que, como ha ocurrido en el pasado, algunos proyectos de conservación ecológica mal planteados vulneren los derechos humanos básicos de las comunidades locales ${ }^{34}$.

\footnotetext{
${ }^{32}$ Incluso ciertas instituciones han manifestado su interés por este problema; por ejemplo, el 19 de mayo de 1999 el Parlamento de Cataluña aprobó por unanimidad una Declaración de Principios sobre Derechos Humanos y Medio Ambiente, convirtiéndose probablemente en el primer Parlamento del mundo que proclama el derecho humano universal a un medio ambiente seguro, saludable y en buenas condiciones ecológicas.

33 BIGUES, J., "La democracia ambiental: un camino complejo", en Biblioteca de ideas (www.iigov.org, página web del Instituto Internacional de Gobernabilidad).

${ }^{34}$ En ese sentido, es dramático el caso de ciertas comunidades esquimales de Alaska. El deterioro por el hombre occidental de los recursos naturales de esas zonas ha traído durante años consecuencias devastadoras para muchas de esas comunidades. Y ahora, deben soportar leyes de "protección de la naturaleza" que les impiden llevar a cabo sus técnicas tradicionales de caza, viéndose obligados a ceñirse a los programas conservacionistas de aquellos mismos que han destrozado sus ecosistemas. El resultado es que sólo una minoría de estos esquimales consiguen hoy día sobrevivir en base a sus antiquísimas costumbres, viéndose el resto obligados a aceptar de forma repentina un estilo de vida occidental. En los últimos años, los índices de alcoholismo, trastornos alimentarios y depresión entre esas comunidades desplazadas ha crecido a un ritmo alarmante. Otro ejemplo válido es el conflicto planteado en relación a la protección del tigre en India, que comentamos más arriba (ver nota a pie núm. 7).
} 
Pero además, el reconocimiento del derecho a un medio ambiente adecuado como derecho fundamental puede tener importantes efectos positivos. Permitiría un mayor acceso de los ciudadanos a la Administración y a la Jurisdicción para denunciar los perjuicios ocasionados al medio ambiente ${ }^{35}$, lo que llevaría a la larga a una reforma en el sistema de administración medioambiental, proporcionando voz y una mayor participación a los sectores implicados. Por el contrario, la situación actual lleva a la sensación de impunidad ante los atentados contra el medio, que "provoca la deriva ambiental y deslegitima las instituciones democráticas frenando un desarrollo sostenible" ${ }^{, 36}$.

Como decíamos antes, se ha sostenido que los derechos de tercera generación plantean serias dificultades de encaje en las categorías dogmáticas. Concretamente, en el caso del derecho a un ambiente adecuado, se plantea cómo resolver la atribución de derechos a un sujeto -las generaciones futuras- que no existen y ni tan siquiera ostentan un derecho a existir. VICENTE GIMÉNEZ apunta que esa dificultad podría ser solventada recurriendo al concepto de "especie humana":

Si bien es obvio que los seres singulares no tienen un derecho concreto a nacer y no se puede exigir responsabilidades individuales a las parejas para asegurar la descendencia, sí existe una obligación jurídica del hombre de continuar su propia especie, existe una responsabilidad colectiva de los hombres para no permitir la extinción de su especie ${ }^{37}$.

Las dificultades desaparecen pues, si analizamos el problema en dos planos distintos, individual y colectivo. Si bien nadie puede ser obligado particularmente a reproducir la especie, el conjunto de la humanidad, la sociedad o sociedades, sí ostentan el deber, en principio ético y ahora también jurídico, de asegurar dicha reproducción preservando las condiciones físicas necesarias para que ello sea posible.

En segundo lugar, se han planteado críticas al concepto restrictivo de ambiente que maneja la Constitución ${ }^{38}$, y por extensión el Tribunal Constitucional y todo el ordenamiento jurídico ambiental. Según dijimos, esta idea centra la problemática ambiental en la protección del los bienes comunes, a través del control de la contaminación. Un importante sector de la doctrina jurídico-ambientalista ha denunciado que ésta es una visión excesivamente superficial de la crisis ecológica, de sus causas y dimensión. Entre los defensores de manejar conceptos amplios de ambiente cabe destacar a COMMONER ${ }^{39}$-quien propone incluir en él tanto la ecosfera como la tecnosfera (elementos fruto de la creación humana)-, y dentro de la literatura jurídica española, la crítica planteada por FUENTES BODELÓN, que puso de manifiesto ya a

${ }^{35}$ La posibilidad de acceso de los ciudadanos y las asociaciones ecologistas a la Jurisdicción contencioso-administrativa es una de las graves deficiencias del vigente sistema de protección jurídica ambiental, lo cual ha sido puesto de manifiesto reiteradamente por los sectores ecologistas y una parte de la doctrina. A este respecto, véase entre otros SANZ RUBIALES, I., "La legitimación de las asociaciones ecologistas en el proceso judicial (Comentario a la STC 34/1994, de 31 de enero)", en Revista de administración pública, № 141, 1996, pp. 155-166.

${ }^{36}$ BIGUES, J., "La democracia ambiental: un camino complejo", op. cit.

${ }^{37}$ VICENTE GIMÉNEZ, T., "Orden ambiental-orden jurídico", op. cit., p. 56.

${ }^{38}$ La Constitución de 1978 se decanta por un concepto netamente restrictivo de ambiente, lo que se demuestra, por ejemplo, cuando diferencia entre la protección del mismo y la conservación y promoción del patrimonio artístico, cultural e histórico de los pueblos de España y de los bienes que lo integren (art. 46).

\footnotetext{
${ }^{39}$ Véase Science and survival, Viking Press, Nueva York, 1966.
} 
principios de los años ochenta que el medio ambiente debe ser contemplado en su globalidad, advirtiendo especialmente que entre naturaleza y cultura existe una estrecha interrelación.

Contra de la opinión de quienes defienden interpretaciones restrictivas, manejar un concepto amplio de ambiente no resulta inoperante. Al contrario, tal visión supone necesariamente un cambio de perspectiva sobre el ambiente, resaltando la complejidad de la realidad ambiental y los innumerables factores que se hallan relacionados dentro de ella, formando conjuntos de ecosistemas en equilibrio y abiertos desde el punto de vista energético, en los cuales el subsistema humano sólo es una parte del conjunto. Se pone así de manifiesto lo insuficiente que resulta introducir ciertas medidas puntuales de control de la contaminación, que es a lo que conducen los conceptos restrictivos. Mantener una noción amplia implica tomar en consideración los intereses ambientales en un mayor número de supuestos, expandiendo así el objeto de protección ambiental. Un concepto restrictivo de ambiente fortalece una perspectiva antropocéntrica, pues implica situar toda la realidad humana fuera de la naturaleza. Frente a ello, mantener una idea expansiva del concepto encaja con la idea de complementariedad expuesta como alternativa a cualquier forma de antropocentrismo.

En este sentido, no cabe duda de que la Constitución de 1978 sostiene una visión marcadamente antropocéntrica de la naturaelaza, subordinando la preservación ambiental de forma exclusiva al mantenimiento de un cierto nivel de bienestar humano. Así, con VICENTE GIMÉNEZ, en el art. 45 CE

la fórmula de la calidad de vida parece adoptada como marco definitorio del espacio jurídico-dogmático tutelable o destinatario de garantías objetivas. Pero, desde el punto de vista ecológico, su sentido aparece en cierta medida restringido, ya que implica una significación antropocéntrica: calidad de vida para la subsistencia y el desarrollo de la persona humana y de sus ámbitos institucionalizados de existencia. Ello se plasmará en dos expresiones finales del artículo: en el apartado $1^{\circ}$, en cuanto que la clase de medio ambiente que se desea es un "medio ambiente adecuado para el desarrollo de la personalidad del hombre", y en el apartado $2^{\circ}$, donde se adoptará como criterio para considerar racional una explotación al medio ambiente el de "proteger y mejorar la calidad de vida" 40 .

La Constitución nace con un importante desfase en relación a la nueva sensibilidad ecológica que ya en los años setenta advertía que la preservación ambiental requiere un cambio de perspectiva, una nueva ética que entienda que la naturaleza debe ser protegida en sí y para sí, y no en relación a una cierta "calidad de vida" humana, que desplaza peligrosamente el discurso al terreno del desarrollo económico continuo. La creencia de compatibilidad entre crecimiento económico constante y sostenibilidad ecológica, axioma de lo que aquí hemos llamado capitalismo verde y también de la Ecología de Mercado, lejos de aportar soluciones eficaces, está provocando una monetarización de la naturaleza, asumiendo la creencia de que los daños ambientales pueden ser compensados económicamente, bien a través de la intervención pública coactiva -principio quien contamina paga-, bien a través del sistema de precios en el Mercado. Pero de esta cuestión nos ocuparemos en la parte final de este trabajo.

Siguiendo con la evaluación de la política ambiental, hay que referirse al surgimiento del llamado Derecho ambiental, como una especialización dentro del

\footnotetext{
${ }^{40}$ Vicente Giménez, Teresa, “Orden ambiental-orden jurídico”, op. cit., p. 81.
} 
Derecho administrativo. Lo cierto es que, tal y como advierte GORDILLO FERRÉ, los partidarios de la conformación de esa nueva rama del Derecho no se han preocupado de tratar la orientación general de las respuestas que el Derecho debe dar a la crisis ecológica, sino sólo sobre la fundamentación del Derecho administrativo ambiental que, en todo caso, sólo es una parte de la cuestión. Si manejamos un concepto amplio de ambiente -incluyendo también la "tecnosfera" y la propia sociedad y cultura humanasnos daremos cuenta de que, en realidad, todo el ordenamiento jurídico recae sobre él. De ahí que no tenga sentido distinguir entre "normas ambientales" y "no ambientales", y por lo tanto identificar el Derecho ambiental con un conjunto normativo adscrito al Derecho administrativo. Aunque este tipo de norma sean necesarias, ése no debe ser el objetivo al que apuntar, sino que sólo debe ser un punto de partida. Adoptando la expresión acuñada por François OST, el objetivo debe ser un auténtica ecologización del Derecho. Según GORDILLO FERRÉ esto exigiría una introducción capilar y difusa de criterios ambientales en todo el Ordenamiento jurídico, paralelamente a una ecologización de la política, de la economía y de la cultura ${ }^{41}$.

Hacia esa incorporación de principios ecológicos en todas las ramas del Derecho apuntan los estudios realizados por FUENTES BODELÓN sobre la necesidad de un pacto ambiental. Este autor advierte que el origen público de las normas ambientales, de contenido netamente coercitivo, puede ser adecuado para resolver problemas ambientales graves, que exigen medidas correctivas inmediatas basadas en el valor ejemplificador de las penas ${ }^{42}$. Sin embargo, señala cómo una visión holística de los problemas ambientales hace preciso acudir a otros medios, que sean compatibles con los anteriores. Estas actuaciones pueden ser de muy diversa índole, pero principalmente deben tender hacia una consideración interactiva de los aspectos públicos y privados, hacia medidas de prevención o cautela de forma preferente a las actuaciones correctoras, a la democratización de la gestión ambiental, y especialmente a la incorporación de elementos voluntarios en el ordenamiento ambiental. Esta última medida consistiría básicamente en la introducción de técnicas e instrumentos de Derecho privado, debidamente actualizados, en la protección del medio ambiente. Se trataría de potenciar el papel del "pacto" en el terreno jurídico ambiental, por ejemplo, facilitando el cumplimiento voluntario de las exigencias ambientales sin proyectar directamente la amenaza de sanción, o introduciendo la posibilidad de realizar acuerdos para la terminación convencional de procedimientos administrativos.

Este tipo de medidas, además de evitar una excesiva inflación del Derecho público ambiental, retomaría el papel esencial "desempeñado por el pacto en la constitución del Estado de Derecho"43. Lo cual se vería plasmado en la creación de un nuevo pacto ambiental, que tendría a su vez un doble ámbito: un pacto tácito, suscrito por la generalidad de la sociedad, y cuya finalidad sería despertar una conciencia ambiental y

\footnotetext{
${ }^{41}$ Este autor afirma que sólo así el proyecto del capitalismo verde podría llegar a buen término. Esa ecologización exigiría una mayor intervención pública en la actividad econòmica -mediante controles preventivos y tasas-, limitación de la movilidad de las empresas multinacionales para permitir el cumplimiento de las medidas ambientales, no sólo a nivel local sino global, imposición de restricciones a la propiedad privada y también a la soberanía de los Estados -restringiendo las políticas militares y otras actividades, por motivos ecológicos-. GORDILLO FERRÉ, J.L., "Del Derecho ambiental a al ecologización del Derecho", op. cit., pp. 328 y ss.

${ }^{42}$ FUENTES BODELÓN, F., "Hacia el necesario pacto ambiental", en Revista de Derecho Ambiental, no24, 2000, pp. 97-111.

${ }^{43}$ Ibídem, p. 102.
} 
un creciente compromiso de la sociedad con el ambiente; y otro de carácter expreso, por el sector de la población que desempeña actividades contaminantes, y que iría dirigido a la asunción de un comportamiento ambientalmente adecuado de forma voluntaria.

\section{- Hacia un nuevo pacto social.}

En una línea similar a quienes proponen una transformación global del Derecho, la política, la economía y la cultura para incorporar así criterios ecológicos de forma difusa, hay autores que han propuesto toda una reformulación del Estado en términos ecológicos, replanteando el origen de su legitimidad. A esta dirección apunta la propuesta de LETTERA, sobre la construcción de un nuevo Estado ambiental ${ }^{44}$. Éste consistiría en un nuevo modelo de organización al que tender, caracterizado por perseguir el ideal del desarrollo sostenible a partir de los principios de la solidaridad económica y social, reconociendo además a los ciudadanos el derecho a exigir un uso racional del patrimonio natural.

Otra posible alternativa pasaría por una redefinición de la teoría del pacto social. GARRIDO PEÑA opina que esta teoría "es perfectamente compatible y aplicable a la nueva cultura que la ecología propone". La operación consistiría en una relectura de la misma, deshumanizando el contenido del pacto, "a favor de una idea más integral de lo humano, una idea ecológica y vitalista" 45 . Frente al antiguo pacto, basado en la cultura burguesa y sostenido sobre su idea de propiedad y del bien, este otro introduciría la nueva sensibilidad ecológica, haciendo posible un antropocentrismo débil y una sociedad sostenible.

A partir de esa idea, SERRANO MORENO formula una propuesta de enfoque del sistema jurídico ambiental estructuralmente idéntico al realizado por FERRAJOLI para el Derecho penal. Se trataría de realizar el mismo ejercicio que el autor italiano ha efectuado para la construcción de su Teoría general del garantismo, para aplicarla al terreno de la protección ambiental. Según ambos autores, debe partirse de que un Estado de Derecho no es simplemente aquél en el que sus poderes están regulados en su interacción por las leyes, sino que exige un segundo requisito de tipo sustancial, consistente en que sus poderes estén orientados exclusivamente hacia la garantía de los derechos fundamentales de los ciudadanos. Lo que SERRANO MORENO propone es incluir dentro de ese núcleo inviolable de derechos fundamentales los derechos de tipo ambiental. Los poderes públicos asumirían de ese modo el deber de no lesionar ni los derechos de libertad ni el entorno, y el deber de satisfacer los derechos sociales y mejorar el entorno. La legitimidad del Estado dependería también del respeto y promoción de esos derechos ambientales.

Esta transformación exige, como decíamos antes, una redefinición del tradicional pacto social, entendiéndose ahora -en expresión de GARRIDO PEÑA- como un "pacto por la vida". Este pacto surgiría por tanto sobre la regla básica de que sobre la vida no se puede decidir, ni tan siquiera por mayoría, recuperando así la premisa básica del

\footnotetext{
${ }^{44}$ Vid., Lo stato ambientale: il nouvo regime dele risorse ambientali, A. Giuffrè, Milán, 1990.

45 "La Ecología como Política", en GARRIDO PEÑA (comp.), op. cit., p..
} 
Estado de Derecho, ahora en términos ecológicos ${ }^{46}$. En definitiva, se trata de repensar la idea de los derechos naturales configurada por el pensamiento iusnaturalista y contractualista de la Ilustración -derechos inalienables e imprescriptibles- añadiendo simplemente nuevos derechos. Situando el eje del nuevo pacto en la vida y no en la propiedad, los sujetos firmantes del pacto se expanden, incluyendo, no a quienes poseen recursos, sino a quienes viven.

\section{Reconsideración del Estado moderno desde la perspectiva ecológica}

Muchas de las alternativas expuestas a la actual política ambiental comparten el plantear una mayor intervención del Estado como solución al deterioro ecológico, ampliando y profundizando la actividad estatal en defensa del ambiente. Sin embargo, esa afirmación debe ser matizada, ya que cualquier alternativa a la política ambiental vigente debe partir de una revisión más amplia del actual modelo político. Un simple fortalecimiento del intervencionismo estatal desde las estructuras existentes presentaría igualmente graves deficiencias para alcanzar una sociedad sustentable. Estas dificultades derivan tanto del propio concepto de Estado-nación, como de la lógica burocrática que rige la actividad de los entes públicos. Podría decirse que en el contexto actual un desarrollo sustentable sólo puede alcanzarse mediante un incremento de la intervención pública, pero que, quizá, el marco más aconsejable para ejercer esa intervención no sea la estructura estatal que conocemos.

En primer lugar, los conceptos tradicionales de Estado-nación y soberanía deben ser revisados desde un punto de vista ecológico. El origen de estas nociones políticas puede ser reconsiderado ecológicamente, como expresión de una ideología territorialista de signo excluyente, guiada por la necesidad de instaurar flujos energéticos y de materiales en radios de influencia progresivamente más amplios, como requisito para la finalidad de crecimiento económico aneja al origen del capitalismo ${ }^{47}$.

Es evidente que, al igual que el resto de especies animales, todo grupo humano necesita conseguir una determinada cantidad de energía exosomática y endosomática para desarrollar su vida, para lo cual requiere de una determinada porción de territorio. Esta exigencia determina que el ser humano manifieste un cierto comportamiento territorialista. Ahora bien, éste puede adoptar formas diversas, pudiendo conducir a la convivencia, a la cooperación, al mutualismo, o, por el contrario, ser de signo excluyente. La aparición de esta última modalidad está ligada a situaciones de escasez de recursos de los que adquirir la cantidad de energía exosomática requerida por el

46 SERRANO MORENO, J.L, "Ecología, Estado de Derecho y Democracia", en Anuario de Filosofía del Derecho, 1993, recuerda que el Estado moderno nace primordialmente como Estado de Derecho y no como Estado democrático, de forma que la primera regla del pacto constituyente no es que sobre todo se debe decidir por mayoría, sino que no sobre todo se puede decidir o no decidir ni si quiera por mayoría.

${ }^{47}$ Una explicación más detallada del surgimiento del Estado-nación desde una perspectiva ecológica ha sido desarrollada por GARRIDO PEÑA y GONZÁLEZ DE MOLINA en "La cuestión nacional desde la ecología política. Algunos elementos de análisis”, Ecología Política No13, 1997, pp. 125-155 y en "La cuestión nacional: una propuesta desde la Ecología Política", en Anales de la Cátedra Francisco Suárez, No31, 1994, pp. 101-110. La realidad estatal ha sido abordada también desde la perspectiva ecológica por GARRIDO PEÑA en La ecología política como política del tiempo, Comares, Granada, 1996. Aquí sólo recogemos las líneas generales de su argumentación. 
grupo. Pero debemos tener presente que la aparición de la escasez no depende únicamente del tamaño del grupo, de la densidad de población, sino sobre todo del sistema social que el mismo adopte ${ }^{48}$. No sólo al número de individuos, sino también al modelo de vida seguido y al grado de complejidad de las relaciones intrasociales. Así, tal y como supuso el origen del capitalismo, un incremento significativo de los niveles de consumo sólo puede lograrse gracias a la extracción de una mayor cantidad de materiales y energía del territorio, y la adopción de nuevas técnicas en el proceso de producción (especialización productiva, división del trabajo). Siguiendo estas coordenadas, un crecimiento continuado del volumen de consumo requiere paralelamente el incremento del territorio controlado por el grupo, y una política excluyente respecto a la obtención de los recursos del mismo, no sólo por el agotamiento de la capacidad de carga de las zonas explotadas originariamente, sino también porque la división del trabajo se hace tan compleja que requiere la implicación de áreas más amplias y mayor número de población. Desde esta premisa puede explicarse "el fenómeno del nacionalismo decimonónico, del imperialismo y del actual proceso de globalización como estadios sucesivos e inevitables del incremento de la división social del trabajo" "49. En definitiva, el aumento del consumo exosomático de una población sólo es posible a través de la apropiación de la capacidad de carga de otros ecosistemas, de la ampliación de los flujos de energía y materiales, que en economías orgánicas son locales y de tipo cerrado, desde lugares cada vez más lejanos. Por ello, el nuevo sistema productivo exigió la subsunción de los mercados locales, de tipo orgánico y tradicional, en un solo mercado nacional y la creación de una nueva unidad político-territorial capaz de garantizar un mercado normalizado, de homogeneizar el nivel de precios y el sistema de tributos, etc. Por lo tanto, uno de los fines esenciales del nuevo Estado-nación (aunque no el único) fue el de posibilitar los flujos de energía y materiales en esos nuevos radios de actuación, aumentar su tamaño (militarmente) si fuese preciso, definir los recursos disponibles, asegurar su disponibilidad y el de la mano de obra, etc. Como advierte GARRIDO PEÑA,

El Estado-nación necesita establecer unas coordenadas culturales homogéneas como base de su propia posibilidad; coordenadas que terminan por englobar la diversidad y pluralidad e incluso por eliminar las culturas ambientalmente adaptadas a unidades territoriales más pequeñas ${ }^{50}$.

El resultado de todo este proceso es el desarrollo de comportamientos competitivos sobre el territorio de tipo excluyente y depredador, basados en una idea de soberanía que prescinde tanto de un importante sector de la población -en virtud de la relación centro-periferia- como de las generaciones futuras. Además, se trata de una idea de soberanía radicalmente antropocéntrica: el Estado se define como autoridad suprema en un determinado espacio territorial, sobre todos los elementos, humanos y no humanos. No en vano, la noción de soberanía se consolidó de forma paralela a la de la propiedad privada como derecho absoluto, sobre una ideología eminentemente antropocéntrica como es la liberal.

\footnotetext{
${ }^{48}$ A diferencia del resto de especies animales, en cuyos ecosistemas el concepto de escasez está en función exclusivamente de la densidad de población, los seres humanos no poseemos instrucciones genéticas a cerca del consumo exosomático requerido para nuestra subsistencia.

49 GARRIDO PEÑA y GONZÁLEZ DE MOLINA, "La cuestión nacional desde la Ecología política...", op. cit., p. 129.

${ }^{50}$ Ibidem, p. 135.
} 
Quizá, las consecuencias más dramáticas y visibles del comportamiento competitivo y excluyente de los Estados han venido de la mano del desarrollo armamentístico y del fortalecimiento de las defensas nacionales, lo cual está ocasionando efectos devastadores también en el ambiente. El presente ataque contra Iraq es un ejemplo evidente de la utilización de la estructura estatal para garantizar el flujo de materiales en el sentido requerido por el sistema económico; en este caso la materia es el petróleo.

En cualquier caso, lo cierto es que el Estado ha adquirido legalmente el papel de garante de la preservación ecológica en las políticas ambientales de nuestro entorno, por lo que, más allá de su origen histórico, debemos plantearnos su idoneidad para resolver en la práctica este tipo de problemas. Sin embargo, como hemos adelantado, este análisis tampoco arroja resultados muy positivos.

El primer punto débil respecto a la operatividad del Estado reside en su concepción del territorio y el marcado principio de territorialidad sobre el que se construye. La noción identitaria que fundamenta la unidad estatal encuentra un elemento básico en la delimitación de un territorio concreto sobre el que ejercer su soberanía. La cartografía ocupa un papel relevante como elemento de identificación, en ese modo de percibir el territorio, "aparentemente concreto y con perfiles geométricos definidos, pero en realidad abstracto y desligado de su contenido físico-biológico" ${ }^{\text {" }}$. Las consecuencias de esa desconexión entre fronteras político-administrativas y unidades físico-biológicas para la operatividad de las políticas ecológicas son evidentes.

El principio de territorialidad provoca que el Estado se encuentre actualmente sometido a una doble tensión por los problemas de tipo ecológico. Por un lado a nivel local, por las dificultades que, como veremos a continuación, las instituciones estatales presentan para hacer frente a problemas ecológicos puntuales pero complejos. Por otro, el principio de territorialidad estatal se muestra inútil a la hora de afrontar cuestiones globales que exigen de una actuación conjunta ${ }^{52}$. Las relaciones internacionales, basadas en la lógica de los Estados -a través de sus gobiernos- como sujetos de las negociaciones y compromisos, se presentan claramente ineficaces para solventar problemas ambientales de enorme gravedad como el cambio climático, o caminar hacia el desarme nuclear. Los ciudadanos actúan dentro de los Estados nacionales y a nivel del gobierno nacional, por lo que no tienen apenas medios efectivos para debatir ni intervenir en el proceso de toma decisiones a nivel internacional, "dependiendo en muchos casos, como en el de la Unión Europea, de una remota y tecnocrática administración para el conjunto de la ciudadanía" ${ }^{93}$.

Descendiendo a un plano más concreto, la operatividad de las instancias políticoadministrativas se ve cuestionada además por razones que afectan a su propia estructura,

\footnotetext{
${ }^{51}$ Ibidem, p. 130.

52 No obstante, existen algunas excepciones en las que las formas de intervención políticoadministrativa sí son definidas en función de realidades ecosistémicas, como en el caso de las Confederaciones hidrográficas dentro del Estado español. Sin embargo no dejan de ser excepciones en un contexto en el que las fronteras políticas resultan poco menos que ridículas al enfrentarse a problemas ecológicos de enorme magnitud. Pensemos en la nube radiactiva que atravesó Europa tras el desastre de Chernobyl, o en la deriva de la marea negra procedente del Prestige.

${ }^{53}$ VALENCIA SÁIZ, A., "Democracia, ciudadanía y ecologismo político", en Revista de estudios políticos, $\mathrm{n}^{\circ} 102$, octubre-diciembre 1998, p. 92.
} 
a su forma de razonamiento y manejo de los asuntos. DRYZEK ha estudiado las carencias que presentan los sistemas estatales administrativos al intentar dar respuesta a problemas como los de tipo ambiental, resumiendo las mismas en tres puntos fundamentales ${ }^{54}$.

- En primer lugar, expone lo que podríamos llamar un problema de enfoque, denunciando las carencias de la propia racionalidad administrativa a la hora de enfrentarse a problemas de cierto nivel de complejidad. DRYZEK advierte que "la desagregación de problemas, a través de la división administrativa del trabajo, significa diversos aspectos de problemas complejos artificialmente separados unos de otros". Enfrentarse a la dimensión ecológica de un asunto puede resultar muy complejo, ya que los factores de degradación ambiental derivan a menudo de la interconexión de diversos factores, y además suelen entran en juego condicionantes socio-económicos que no pueden ser dejados de lado. Considerar de forma aislada elementos que no son sino caras de una misma moneda nos sitúa de nuevo ante el Proyecto Tigre de la India, o ante la situación de las comunidades esquimales de Alaska.

- Este autor plantea además dos problemas de tipo orgánico. Por un lado denuncia lo que podría definirse como rigidez de los entes administrativos ante problemas de tipo complejo. Si bien es cierto que las organizaciones burocráticas pueden ser eficaces para la realización de tareas programadas, más o menos rutinarias, la experiencia demuestra que difícilmente pueden serlo frente a los variados y complejos problemas ambientales. Inevitablemente, "grandes y centralizadas instituciones generan grandes y centralizadas soluciones a los problemas...” y “...el carácter jerárquico de las organizaciones significa que cualquier fracaso o mala interpretación en cualquier punto de la cadena administrativa puede resultar devastador".

- En tercer lugar, y directamente relacionado con lo anterior, puede afirmarse que los sistemas jerárquicos obstruyen habitualmente la libre circulación de información, algo esencial para la solución de problemas no rutinarios. Por lo que, de nuevo, una estructura jerárquica, en contra de lo que se suele creer, resulta inapropiada para la resolución de problemas realmente complejos.

Las carencias de la lógica institucional-burocrática a la hora de resolver asuntos complejos ha sido puesta de manifiesto por otros autores en los distintos ámbitos de actuación estatal. Así, HULSMAN, aunque en un ámbito distinto como es el proceso penal, ha señalado cómo la práctica y discurso institucional excluye inevitablemente la diversidad, ya que toda institución, para convertir en manejables los asuntos, los reduce al mismo tiempo a su naturaleza de institución, con lo cual se simplifica prodigiosamente su complejidad, y con ello su auténtica realidad ${ }^{55}$.

Por último, apuntar que tampoco el modelo de Estado que en las últimas dos décadas se ha vivido en las zonas económicamente desarrolladas del planeta -el Estado del Bienestar- ha servido para atajar el deterioro ecológico. Más bien, como advierte FERNÁNDEZ DURÁN, ese modelo ha sido fruto de circunstancias políticas y sociales, del propio capitalismo de la época y del marco geoestratégico mundial, que hicieron

\footnotetext{
${ }^{54}$ Véase su artículo "Ecología y democracia discursiva: más allá del capitalismo liberal y del Estado administrativo", en Ecología Política. Cuadernos de debate internacional, nº16, 1998, p. 99.

${ }^{55}$ Véase HULSMAN, L., Sistema penal y seguridad ciudadana: hacia una alternativa, Ariel, Barcelona, 1984.
} 
factible que en los espacios centrales (únicamente) se desarrollase esa situación. Pero "las pretendidas conquistas del Estado del Bienestar fueron posibles por el alto crecimiento económico en esa etapa, que profundizó los desequilibrios ecológicos, y por las relaciones de explotación centro-periferia, que se intensificaron también en dicho periodo". Ciertamente, el Estado se presenta hoy como una "poderosa, costosa, compleja, burocrática, jerarquizada y antidemocrática estructura, que necesita también del crecimiento económico continuo para mantenerse" $" 56$. Y, además, la reestructuración a que el capitalismo globalizado somete hoy al Estado hace mucho más difícil cualquier tipo de reforma encaminada hacia la sostenibilidad, sobre todo atendiendo a las dificultades que las vías institucionales actuales están presentado para acometer este tipo de reformas.

La superación de la situación actual requiere una nueva formulación de la vida política, entendiendo que la gestión de los asuntos públicos, entre ellos los ambientales, no puede suponer su tajante separación de la masa social afectada por los mismos a favor de su asignación a entes altamente burocratizados. Entes que tienden a obviar determinados intereses que entran en juego en la toma de cualquier decisión pública.

En los dos últimos apartados de este trabajo trataremos de argumentar que el camino más adecuado para lograr una sociedad sostenible a todos los niveles (ambiental y humano) pasa, por un lado, por la implementación de un sistema político basado en una democracia sustancial o directa; una democratización radical de la vida pública que permita una gestión descentralizada y local de los recursos requeridos por cada grupo social. Y por otro lado, por la superación de los fundamentos en que se basa el vigente sistema económico capitalista, en cuanto a la consideración y reparto de los recursos del planeta.

\section{ECOLOGÍA Y DEMOCRACIA}

1. Relación entre ecología y democracia: ¿un vínculo contingente o necesario?

Acabamos de apuntar escuetamente que las deficiencias de la política ambiental podrían superarse a través de una profundización en los fundamentos de la democracia, compartiendo los planteamientos de la corriente que, dentro de la ecología política, ha propuesto una participación más directa y una gestión descentralizada como base de una sociedad sostenible. Sin embargo, esta teoría ecopolítica ha sido cuestionada y acusada de presentar debilidades tanto desde un punto de vista teórico como práctico. Hay quienes han sostenido que la defensa de un vínculo estrecho entre democracia y ecología está fuera de lugar, bien por considerar que la preservación ecológica no requiere de un modelo político concreto o, yendo más lejos, por pensar que ambos conceptos presentan graves problemas de compatibilidad.

En un plano abstracto, la discusión a cerca del binomio ecología-democracia gira en torno a la naturaleza del vínculo que une ambos conceptos. La pregunta fundamental es si la relación entre ecología y democracia es de carácter contingente, o bien es un

${ }^{56}$ FERNÁNDEZ DURÁN, R., Capitalismo global, resistencias sociales y estrategias de poder, Ecologistas en Acción - Movimiento contra la Europa de Maastricht y la globalización económica, Madrid-Pelegrina, agosto 2000. 
vínculo necesario en todo caso. La respuesta determinará que la defensa de un modelo de sociedad democrático se sitúe o no dentro del núcleo duro de los planteamientos de cualquier política ecológica sostenible.

Partiendo de un concepto de democracia amplio y genérico, como sistema que persigue la igualdad social y política entre todos sus miembros, la contingencia parece clara en uno de los sentidos de la relación: una sociedad democrática no tiene por qué ser ecológica (sustentable). Nos refiramos a una democracia liberal o a un sistema de democracia más directa, una determinada sociedad organizada de tal forma, y aunque mantenga un régimen de igualdad entre sus miembros, puede adoptar decisiones que proyecten consecuencias nocivas a su entorno. Pero la cuestión no está tan clara al referirnos al otro sentido de la relación. La cuestión es: ¿toda sociedad sustentable debe ser necesariamente democrática?, y, en caso afirmativo, ¿qué tipo de democracia debería ser ésta?

Planteando el interrogante en términos generales y abstractos no es fácil llegar a una respuesta unívoca. A priori, parece sencillo imaginar una sociedad no democrática pero ambientalmente respetuosa, por ejemplo en una oligarquía donde sus decisiones se adoptasen siempre de acuerdo con los principios necesarios para garantizar la sustentabilidad del grupo. Todos tenemos en mente culturas indígenas pre-alfabetizadas, cuyas estructuras sociales pueden ser marcadamente antidemocráticas o desigualitarias, que sin embargo han vivido durante miles de años en armonía con el ecosistema natural en que habitan. Pero estas afirmaciones deben matizarse. Respecto a las sociedades prealfabetizadas, porque, como señala BOOKCHIN, es necesario romper con la idea romántica del aborigen en armonía con su entorno. No cabe duda de que en ocasiones esa armonía existió y aún existe, pero no faltan ejemplos de casos contrarios. Como el supuesto de muchas comunidades indias precolombinas de Norteamérica, creadoras de las grandes praderas del Medio Oeste mediante la quema sistemática de bosques para conseguir pastos para el ganado, o la caza masiva de ciertas especies animales - más allá de lo que exigían sus necesidades- llegando a poner en peligro su supervivencia en algunas zonas. Otro ejemplo puede ser el de los pigmeos del África central, cuyo trato hacia los animales no humanos es sorprendentemente cruel, llegando a infringirles sufrimiento por mera diversión, sin mostrar ningún respeto hacia la vida animal salvaje ${ }^{57}$.

Por otro lado, manteniendo un concepto amplio de naturaleza como el que hemos defendido, en la cual también se incluya la sociedad humana, encontraremos que muchas de esas culturas pre-alfabetizadas desigualitarias y fuertemente jerarquizadas no pueden ser entendidas como sociedades sustentables. La opresión física y psíquica que en algunas de esas culturas se ejerce sobre ciertos elementos del ecosistema humano, habitualmente las mujeres -piénsese en tradiciones como la ablación del clítoris en algunas sociedades indígenas africanas-, impide que podamos calificarlas de sostenibles.

\footnotetext{
${ }^{57}$ Como advierte BOOKCHIN, M., La ecología de la libertad, op. cit., p. 68 y ss., no se trata de "difamar" a las culturas aborígenes, equiparándolas al comportamiento de las compañías madereras o industrias cárnicas actuales, ni mucho menos. Simplemente es necesario romper con el ideal romántico posmoderno de la cultura tribal en perfecta armonía con el entorno, pues en ocasiones la realidad fue bien distinta, llegando a causar graves daños a la vida salvaje.
} 
Un argumento a favor de la necesidad del vínculo entre ecología y democracia podemos hallarlo si, volviendo de nuevo a los estudios de BOOKCHIN, atendemos al origen de este tipo de prácticas explotadoras -hacia el medio no humano y dentro de la propia sociedad- en algunas culturas aborígenes. Según éste y otros autores, dichas prácticas responden a una transformación profunda que se originó en las sociedades del post-Neolítico, hace unos cinco mil años. En ese periodo parece haberse producido una auténtica revolución en cuanto a la cultura y a la organización social, política y económica, instaurándose un sistema de tipo patriarcal heredado hasta el día de hoy (es la denominada revolución patriarcal). Aunque ese proceso y el modo en que ocurrió es complejo y discutido entre antropólogos e historiadores, baste aquí con señalar que BOOKCHIN fija en ese periodo el paso de lo que él denomina sociedades orgánicas -sociedades propias de la cultura neolítica, inspiradas en una profunda igualdad e interdependencia entre sus miembros, de tipo matriarcal, realmente integradas "en armonía" en el ecosistema natural- a sociedades que interiorizaron el concepto de jerarquía -basadas en el dominio de la mujer por el hombre y del joven por el anciano, de corte patriarcal, y en las que el guerrero adquiere un rol social predominante-. A partir de entonces habrían empezado a desarrollarse estructuras sociales y prácticas que proyectaban relaciones de dominio y explotación hacia ciertos miembros de la sociedad y hacia el entorno no humano ${ }^{58}$. No por casualidad, esa incipiente revolución patriarcal coincide temporal y geográficamente con el origen de la concepción antropocéntrica de la realidad ${ }^{59}$.

Estos hechos parecen apoyar la idea de que el sistema político necesario para una sociedad sustentable es la democracia, entendiendo como tal aquél en el que los individuos integrantes de la sociedad se organizan en un régimen de igualdad social, política, y también económica.

Si bien lo anterior puede ser discutido a través de una interpretación diferente de los datos aportados por los estudios antropológicos, las cosas parecen estar más claras si, concretando el debate, nos referimos al vínculo entre ecología y democracia en nuestra sociedad contemporánea. La diferencia fundamental en este tema con las sociedades

\footnotetext{
${ }^{58}$ En palabras de VICENTE GIMÉNEZ, “El nuevo paradigma de la justicia ecológica”, en Justicia ecológica y protección del medio ambiente, op. cit., p. 67, "la opresión que ha sufrido lo femenino frente a lo masculino, en sintonía con la degradación y explotación que sufre nuestro planeta, ha sostenido un desequilibrio fundamentador de relaciones injustas, desde donde revisar la propia teoría de la justicia. Por ello, rescatar lo femenino está ligado a rescatar la riqueza y el equilibrio de la tierra”. El fenómeno de la "revolución patriarcal" ha sido abordado ampliamente por autoras representantes del ecofeminismo. En el Estado español cabe citar especialmente a Casilda RODRIGÁÑEZ y Ana CACHAFEIRO, quienes han tratado este tema en libros como La represión del deseo materno y la génesis del estado de sumisión inconsciente (Nossa y Jara, Madrid, 1995), y en artículos como "Matricidio y Estado terapéutico" (en Archipiélago, cuadernos de crítica de la cultura, n²5, pp. 75-82) o "Por una maternidad antipatriarcal" (en Ekintza Zuzena, nº19, pp. 39-47). Recientemente ha sido publicado el libro de Casilda RODRIGÁÑEZ El asalto al Hades. La rebelión de Edipo, $1^{a}$ parte (Traficantes de sueños, Madrid, 2002), en el que se aborda nuevamente el origen de la sociedad patriarcal. El tema de la maternidad apatriarcal y sus implicaciones ecológicas ha sido desarrollado en España también en diversos textos por la "Asociación Los Arenalejos para la Investigación y el Desarrollo de la Ecología Social” (ALAIDES), grupo federado a Ecologistas en Acción-Málaga (arenalaides@eresmas.com).

${ }^{59}$ A tenor de los datos históricos, las primeras manifestaciones de ambos fenómenos -organización patriarcal de la sociedad y concepción antropocéntrica del mundo- parecen darse simultáneamente, a finales del Neolítico y en la zona geográfica comprendida entre el mar Mediterráneo y el Caspio.
} 
pre-alfabetizadas proviene, entre otras cosas, por la capacidad de agresión hacia el medio, que en nuestros sistemas sociales es infinitamente superior, lo que se traduce en una mucho mayor complejidad de los problemas ecológicos que pueden plantearse.

Pero, dijimos, la doctrina no es pacífica en este asunto. Para muchos autores, la relación entre democracia y ecologismo está lejos de ser necesaria, e incluso podría ser excluyente. Se han denunciado ciertos puntos oscuros, principalmente en la teoría política ecológica radical, que generan tensiones entre ambos conceptos. Podríamos resumirlos así ${ }^{60}$ :

- Se advierte que el ecologismo postula como axioma que la estabilidad de un ecosistema depende esencialmente de la diversidad que exista en el mismo, lo cual en el terreno social se traduce en una necesaria tolerancia de la peculiaridad y de generosidad con respecto a las diversas opiniones. Sin embargo, esto choca frontalmente con la rigidez de las normas y principios que señalan como necesarias para instaurar una sociedad sustentable a pequeña escala; se pretende respetar formas diversas de conducta, al mismo tempo que se defiende de forma rígida lo que se entiende como "bueno" para diseñar el modelo social.

- Suele denunciarse la existencia de una tensión entre resultado y procedimiento. Se dice que la política verde tiende a priorizar el primero sobre el segundo, lo que ha llevado en ocasiones a que los ecologistas caigan en actitudes autoritarias, exigiendo determinados resultados con independencia del procedimiento seguido para adoptar esas decisiones.

- Además suele decirse que, realmente, los fines de la sustentabilidad no exigen para su realización de un modelo político concreto. Ello generaría cierta ambigüedad dentro del pensamiento ecologista a la hora de defender una democracia participativa o radical.

Todo lo anterior motivaría que dentro de la teoría política ecologista la defensa de la democracia resulte débil en comparación con otros principios para gestionar una sociedad sustentable. Pero estos argumentos han sido ampliamente rebatidos. Respecto a las mencionadas "actitudes autoritarias", si bien éstas han podido existir dentro del ecologismo de forma aislada y puntual, esa afirmación carece de fundamento alguno a nivel genérico, y suele ser más bien un argumento difamatorio. La realidad diaria de cientos de agrupaciones ecologistas demuestran cómo éstas están a su vez implicadas en otras iniciativas como el feminismo, el pacifismo y la defensa de las minorías raciales y étnicas, de las cuales nadie parece dudar su carácter democrático.

Por otro lado, siguiendo a ECKERSLEY, la supuesta tensión entre procedimiento y resultado desaparece si concebimos la política verde (radical) como una política emancipadora, cuyo fin prioritario es aumentar al máximo la autonomía tanto de los seres humanos como la de los demás seres que forman parte de la naturaleza ${ }^{61}$. En

${ }^{60}$ Estos argumentos se encuentran más desarrollados en VALENCIA SÁIZ, A., "Democracia, ciudadanía y ecologismo político", op. cit., pp. 77-94.

${ }^{61}$ Al igual que Murray BOOKCHIN, Robyn ECKERSLEY ha defendido la existencia de un vínculo fuerte entre la ecología y una democracia participativa de tipo descentralizado. Véase, entre otros, sus trabajos Environmentalism and Political Theory: Toward an Ecocentric Approach, Suny Press, Albany 
efecto, en la línea marcada por los planteamientos de BOOKCHIN, las teorías políticas ecologistas ponen el acento en la interdependencia entre todos los elementos de los ecosistemas, de forma que cada uno de ellos es imprescindible para la viabilidad de los demás. Esta noción simbiótica de los elementos naturales (humanos y no humanos) genera un concepto intenso del principio de igualdad, que en el plano social sólo puede ser cumplido a través de un sistema democrático.

Incluso puede decirse que la conciencia ambiental fortalece los principios democráticos. BIGUES advierte cómo esa sensibilidad ambiental "regenera y crea un nuevo sentido de comunidad, más allá de las identidades nacionales y de las fronteras. Integra a su vez la democracia y la justicia como un modo de hacer, decidir, gozar y garantizar los derechos y deberes humanos" ${ }^{\prime 62}$. La democracia es además el único sistema de organización social y político que acepta como premisa básica la inestabilidad y la asimetría, es decir, que se construye sobre el sustrato de una ontología relativista y conflictual. Se convierte así en un "sistema vivo, que no pretende un punto de cero de equilibrio y perfección", por lo que GARRIDO PEÑA define metafóricamente a la democracia como "el sistema político de la termodinámica"63.

2. Qué tipo de democracia para una sociedad sustentable.

Podríamos concluir que la democracia es el sistema socio-político más adecuado, o incluso necesario, para construir una sociedad sustentable, al menos en nuestra cultura altamente industrializada. Sin embargo esto no es decir mucho, si tenemos en cuenta los múltiples sentidos con los que es utilizada la palabra democracia. Antes hemos adelantado nuestra opinión defendiendo un concepto fuerte de democracia, de tipo sustantivo o directo, como estructura política de una sociedad sustentable. Trataremos de fundamentar y concretar algo más esta afirmación.

La primera pregunta que se nos plantea es si el actual sistema democrático, al que nos referiremos como democracia liberal, es adecuado o no para el objetivo propuesto. La tesis defendida aquí es que la democracia liberal resulta insuficiente para las prescripciones políticas del ecologismo. Con VALENCIA SÁIZ, puede decirse que la premisa de ese (nuestro) sistema es que "la ciudadanía, al ejercer democráticamente sus preferencias a través de la elección de sus representantes, define el significado de bien público y por tanto, las instituciones democráticas sólo son un procedimiento neutral que asegura la diversidad de opiniones" ${ }^{\prime 64}$. Sin embargo, la realidad demuestra cómo esa definición de democracia como procedimiento que garantiza la neutralidad en la toma de decisiones no se produce en la práctica.

Para DRYZEK, las dificultades que plantea la democracia liberal, y en general el Estado moderno, se deben a la convivencia en el mismo de tres elementos que aportan lógicas distintas a la resolución de problemas. El Estado moderno supone la unión de la democracia liberal, por un lado, y la burocracia administrativa, por otro, a las que se uno

(NY), 1992 y "Greening Liberal Democracy: The Rights Discourse Revisited", en DOHERTY, B. y DE GEUS, M. (eds.), Democracy \& Green Political Thought, Routledge, Londres, 1996, pp. 212-236.

${ }^{62}$ BIGUES, J., "La democracia ambiental: un camino complejo", op. cit.

${ }^{63}$ GARRIDO PEÑA, "La ecología como política", op. cit., p. 15.

${ }^{64}$ VALENCIA SÁIZ, A., "Democracia, ciudadanía y ecologismo político", op. cit., p. 86. 
como tercer elemento el Mercado. Los dos primeros comparten una misma lógica de resolución, que se fundamenta en la desagregación analítica y el razonamiento en horizontes temporales cortos; la democracia liberal de acuerdo al interés y peso político relativo de determinados grupos sociales, y la otra en armonía con la mentalidad analítica de la burocracia estatal. Aunque ambas tienen en común la idea básica de la fragmentación, la combinación de las dos lógicas produce un resultado aún menos racional, debido a que "cada lógica triunfará en imprevisibles situaciones específicas" 65. El asunto se complica todavía más por la coexistencia de una tercera lógica que se combina con las anteriores, y que es la lógica del Mercado, cuyo tratamiento de los asuntos ambientales se basa en la externalización de costes.

Retomando lo expuesto en el punto anterior sobre la lógica burocrática, podríamos decir que la insuficiencia de la democracia liberal para la plasmación de los principios ecológicos radica en la atribución de la resolución de los conflictos ambientales a una élite reducida, que los aborda con una metodología analítica basada en la fragmentación de los mismos. Y, además, dicha élite no actúa desde una posición de neutralidad, sino que se encuentra negativamente influida por otros criterios no ecológicos -derivados de oportunismos políticos y de su combinación con las exigencias que provienen de la lógica mercantilista-, lo que lleva a menudo a subordinar los principios de la sustentabilidad a otros, ya sean de tipo económico o político. La democracia competitiva, basada en un sistema partitocrático, se orienta estructuralmente hacia el resultado a corto plazo (elecciones), lo que tiene repercusiones negativas para el futuro: nuestras sociedades no están preparadas para afrontar problemas a largo plazo ${ }^{66}$.

Además, la escasa participación social que trae consigo este tipo de democracia representativa lleva consigo el desinterés y alejamiento de la población hacia los asuntos públicos, en este caso los de tipo ambiental. El desinterés favorece el oscurantismo y la no circulación de información sobre dichos asuntos, lo que genera una sensación de impunidad ante las agresiones al medio y favorece la vulneración de las normas de preservación ambiental, incluso por los propios Poderes Públicos (lo cual es tristemente habitual hoy día).

A raíz de la constatación de estos "déficit" que presenta la democracia liberal, se han desarrollado un creciente número de propuestas que se dirigen a subsanarlos, apuntando hacia la radicalización de los principios democráticos: igualdad social y política de todos los miembros de la comunidad. De forma genérica podemos incluir todas estas propuestas bajo el término de democracia ambiental. Aunque con distintos nombres y diferencias puntuales, dichos proyectos coinciden en sus elementos fundamentales, que podríamos sintetizar en tres:

- Derecho a saber: la posibilidad de acceder a la información es ala vez un derecho básico que toda persona debe ver respetada ${ }^{67}$, y un requisito previo indispensable para participar en la gestión de los asuntos públicos.

\footnotetext{
${ }^{65}$ DRYZEK, J.S., "Ecología y democracia discursiva: más allá del capitalismo liberal y del Estado administrativo", op. cit., p. 100 y ss.

${ }^{66}$ HARMS, H., "El modelo NIP contra las deficiencias del sistema democrático representativo para responder a los problemas medioambientales”, en Ecología Política No13, 1997, p. 166.

${ }^{67}$ Debe ser un derecho de toda persona acceder a la información ambiental, sobre la calidad del agua que bebe, del aire que respira, la presencia de industrias contaminantes en su entorno, la composición de los productos alimenticios que consume, o la política estatal sobre la gestión de residuos radiactivos, por
} 
- Derecho a participar: debe superarse el concepto de participación esporádica y de tipo representativo promovido por la democracia liberal, instaurando mecanismos que permitan una participación más directa de la población en los asuntos públicos, y dentro de ellos los de tipo ambiental.

- Asunción de una ética discursiva o deliberativa. La apertura de espacios de democracia directa debe ir acompañada de la adopción por los individuos que intervienen en el discurso de valores como el respeto mutuo, la apertura, la transparencia en las relaciones humanas... para crear así una verdadera opinión pública. Podemos acudir a la racionalidad comunicativa descrita por HABERMAS, que implica un compromiso que impone el hablar y el escuchar, así como el respeto hacia las posiciones reflexivamente asumidas por otros.

Sobre estos tres ejes se han planteado múltiples proyectos de democracia ambiental, que presentan aspectos válidos para un modelo político sostenible. Así, la democracia deliberativa definida por autores como ECKERSLEY propone una adecuación a través del diálogo, y la transformación de la opinión pública a través del debate, caracterizado por una mayor flexibilidad, participación local y descentralización en la toma de decisiones. Lo cual implicaría reconocer los derechos ambientales como prioritarios, asumiendo la estrecha relación entre éstos y los derechos sociales y políticos, debiendo ser aceptados también como parte de los derechos de la ciudadanía.

Por su parte, GARRIDO PEÑA señala que la apuesta de una sociedad sustentable debe serlo por una democracia entendida como forma de vida. Ésta no se limita a ser un sistema de gobierno o un mecanismo para designar quién manda, sino que establece un "conjunto de principios, reglas, valores y creencias que organizan integralmente la vida social" ${ }^{\prime 68}$. Supone una extensión del discurso democrático a todos los poderes posibles, implicando al mismo tiempo un cambio en el concepto de soberanía; ésta no sería ya la respuesta a la pregunta de ¿quién manda?, sino a la de ¿cómo se manda?.

DRYZEK propone una solución más allá del triángulo centralización burocrática/democracia liberal/economía de mercado, a través de una democracia discursiva. Plantea que son los procesos democráticos de tipo deliberativo, entendidos al menos como mecanismos sociales de resolución de problemas, los que mejores condiciones presentan para enfrentarse a tales problemas, toda vez que son los más capaces de adaptarse a contextos cambiantes, los más abiertos a nuevas señales ("retroalimentación positiva") y los que permiten mejor coordinación entre los distintos actores sociales. Siguiendo a HABERMAS, defiende la racionalidad comunicativa advirtiendo ahora su vinculación con la racionalidad ecológica, por las propias condiciones en que el discurso comunicativo tiene lugar. No sólo abre la comunicación a un mayor número y pluralidad de voces, sino que además dificulta la distorsión de la comunicación y tiende a fomentar valores generalizables, de tipo universal, lo cual tiene

poner algunos ejemplos. En los últimos años se ha avanzado algo en este tema, a partir de la aprobación de la Directiva comunitaria de 7 de junio de 1990, sobre la libertad de acceso a la información en materia de medio ambiente. Sin embargo, la respuesta de los Estados ante la misma no ha sido muy positiva, incurriendo en graves retrasos en cuanto a su transposición (el Estado español tardó cinco años en transponerla, lo que finalmente hizo por Ley 38/1995 de 12 de diciembre tras ser multado reiteradamente), dando escasa publicidad y promoción a esta nueva posibilidad, e introduciendo injustificables restricciones a la hora de desarrollarla en cada uno de los ordenamientos estatales.

${ }^{68}$ GARRIDO PEÑA, "La ecología como política", op. cit. 
especial relevancia para garantizar el respeto de intereses propios de elementos no partícipes en las decisiones, como las generaciones futuras u otros seres vivos. Este modelo pasa por la creación de espacios públicos autónomos que permitan el debate sobre ciertos temas que las instituciones tradicionales excluyen, acogiendo una racionalidad discursiva como procedimiento de actuación. Se trataría de espacios a cargo de movimientos sociales relacionados con la paz, la comunidad, la ecología, el feminismo, etc., que surgirían como auténticos proyectos autogestionarios en muchos casos opuestos al Estado, abiertos a la negociación y debate con las instituciones públicas. Se trataría de una recuperación de la sociedad civil, como se viene proponiendo últimamente, ante la pasividad, indiferencia o ineficacia de las estructuras estatales respecto a ciertos problemas como los de tipo ambiental. Esta democracia discursiva permitiría por un lado sensibilizar a la población respecto a los síntomas de desequilibrio en la interacción entre la sociedad y la naturaleza, haciendo posible la implicación de una extensa variedad de voces libres de distorsiones provenientes de estrategias políticas, como ocurre habitualmente en las democracias liberales. Por otro lado, ese mayor índice de participación no tiene por qué suponer un incremento en la complejidad al abordar los asuntos. Al contrario, si se respetan los postulados de la racionalidad discursiva, esta participación múltiple permitiría abordar los problemas en toda su amplitud, y con mucha mayor profundidad que la que deriva de la aplicación de la lógica analítica burocrática ${ }^{69}$.

Un proyecto quizá más detallado de democracia ambiental es el municipalismo libertario, elaborado por representantes de la ecología social como BIEHL y BOOKCHIN entre otros, y que como toda esa corriente de pensamiento ecológico se inscribe en la tradición política libertaria más ligada a la filosofía de KROPOTKIN. Este proyecto trata de plasmar los conceptos de descentralización y organización no jerárquica, e integrar el socialismo con la ecología. Asume básicamente los principios del clásico comunismo libertario, praxis política del anarquismo tradicional, aunque presenta algunas diferencias importantes derivadas de su énfasis el fortalecimiento de la vida municipal y otras cuestiones puntuales ${ }^{70}$.

${ }^{69}$ No obstante, DRYZEK advierte que hoy pueden apreciarse incipientes procesos discursivos promovidos por los propios Poderes públicos. Esto podría deberse a que la consciencia sobre la crisis ecológica ha exigido una respuesta de las instancias de poder, que ha consistido en buscar su propia legitimidad política a través de la introducción de ciertos elementos que hagan más participativo el sistema de democracia. Algunos ejemplos son las consultas públicas que en muchos Estados europeos se han impuesto con motivo de actuaciones referidas a la energía nuclear, el auge de las evaluaciones de impactos sociales y ambientales, la instauración de modelos de planificación participativa... Aunque en el Estado español hoy por hoy este tipo de medidas pueden calificarse de anecdóticas. Vid., DRYZEK, J.S., "Ecología discursiva....", op. cit., pp. 104 y ss. Un mayor desarrollo puede encontrarse en los trabajo de este mismo autor Rational Ecology. Enviromental and Political Ecology, Oxford, Blackwell, 1987; Discursive Democray: Politics, Policy, and Political Science, Cambridge University Press, 1990 y "Political and Ecological Communication", en Enviromental Politics, No4, 1995, pp. 13-31, entre otros.

${ }^{70}$ El proyecto del municipalismo libertario ha sido más desarrollado por Janet BIEHL, sobre todo a través de su libro Las políticas de la ecología social, Virus, Barcelona, 1998. Siguiendo los métodos de análisis de la ecología social, una parte de la obra se destina a realizar un estudio histórico a través de las diversas formas de organización municipal, identificando en varios de ellos rasgos válidos para construir una sociedad municipalista libertaria, constatando los abundantes ejemplos históricos de enfrentamiento entre los municipios y el Estado. La segunda parte de libro se dedica a la descripción detallada de este proyecto político. 
El municipalismo libertario parte de la base de que la solución de la crisis ecológica no puede venir de la mano de un proyecto que el Estado ejecute. Debe implicar la devolución de la fuerza política la pueblo, a la base, y la creación de una literatura y cultura políticas que lleve a la gente a participar activamente, que nos permita así liberarnos, autónomamente, del actual modelo de economía capitalista y de la sociedad y sensibilidad autoritarias ${ }^{71}$. Asimismo, este proyecto analiza críticamente y trata de superar las carencias que han mostrado las experiencias de algunos partidos Verdes, como el caso de los alemanes, que al tratar de buscar soluciones desde arriba han acabado por tener que ceder y abandonar una posición detrás de otra. El municipalismo libertario reclama la esfera pública para ejercer una auténtica ciudadanía, rechazando el "estéril ciclo del parlamentarismo y la mistificación del mecanismo de partidos políticos como medios de representación pública" ${ }^{, 72}$. Su propósito es el de trabajar las incipientes o latentes posibilidades democráticas que hoy existen en nuestras sociedades, para dirigirse hacia nuevas configuraciones sociales radicales, una sociedad comunitaria orientada hacia la satisfacción de las necesidades humanas respondiendo a las exigencias ecológicas y desarrollando una nueva ética basada en la cooperación y el compartir. Esto implica, políticamente, una redefinición de la política en la que la gestión de la comunidad y las políticas públicas se realcen en asambleas cara a cara basadas en la ética de la complementariedad y la solidaridad. Y económicamente, un sistema de municipalización de la economía, que evite su centralización en empresas nacionalizadas o su reducción a diversas formas de control capitalista. Y esto no es una mera utopía; los ecologistas sociales afirman que la potencialidad de este proyecto radica en que es precisamente en el municipio donde desarrollamos nuestra vida. No sólo es el espacio en el que convivimos, sino también el auténtico espacio económico en el que trabajamos ${ }^{73}$. Para abordar problemas que trascienden las fronteras de lo local se acudiría a la estructura confederal como mecanismo de coordinación.

\section{- Núcleos de Intervención Participativa, un ejemplo práctico de democracia discursiva $^{74}$}

Para ilustrar lo que venimos exponiendo, puede citarse una experiencia concreta de democracia discursiva que se ha puesto en marcha en diversas poblaciones del Estado español. Se trata de los Núcleos de Intervención Participativa (NIP), mecanismos orientados a promover la participación de los ciudadanos, y que se ha empleado a nivel municipal para tratar controversias que pudieran dañar la convivencia de un municipio.

${ }^{71}$ BOOKCHIN, M., "Nosotros los verdes, nosotros los anarquistas" en VV.AA., Teorías y prácticas del ecologismo social, Oxígeno, 2002. El texto puede consultarse también en la biblioteca virtual de CGT (http://www.cgt.es/biblioteca.html)

${ }^{72}$ PÁEZ, A.G., "Del desarrollo a la ecología social", en Revista Mad nº1, septiembre 1999, Dep. de Antropología, Universidad de Chile.

${ }_{73}$ MORSE, CH., "Ciudades radicales y revolución social. Entrevista con Janet Biehl", otoño 1997, en VV.AA., Teorías y prácticas del ecologismo social, Oxígeno, 2002.

74 Información obtenida de los artículos de AZURZA, I., "Hiritarren partaidetza hirigintz plangintzan" (trad. Como "Los sistemas de participación NIP") en Euskonews, n9, 6-19 noviembre 1998 y de HARMS, H., "El modelo NIP contra las deficiencias del sistema democrático representativo para responder a los problemas medioambientales", en Ecología Política Nº13, 1997, pp. 165-168. 
En todas las experiencias llevadas a cabo se siguió un procedimiento similar. Planteado un determinado problema, los intervinientes en los NIP son elegidos por sorteo, entre las personas inscritas en el padrón municipal, con el requisito de que sean mayores de 18 años. Cada NIP se compone de 25 personas, siendo la asistencia totalmente voluntaria. Los NIP funcionan de acuerdo a la dinámica de grupo, diferenciándose dos fases en el proceso:

- Una primera fase de información, en la que las 25 personas se reúnen con el fin de adquirir conocimientos sobre el asunto. En esta fase se puede escuchar a políticos, técnicos, representantes de sociedades públicas, etc. a los que se les da la oportunidad de exponer sus puntos de vista. Además, se pueden celebrar mesas redondas y excursiones.

- La segunda fase es de debate. En ella los participantes, reunidos en grupos de cinco, discuten y evalúan las posibles alternativas. Los grupos de cinco personas van variando de formación, con el fin de evitar posturas preponderantes dentro de ellos. La duración de ambas fases dependerá en cada caso del tipo de problema que se esté discutiendo.

Este tipo de procedimiento puede ser adecuado para tratar asuntos de muy diversa índole, y por supuesto también de tipo ambiental. Entre las experiencias llevadas a cabo, quizá merezca la pena resaltar, por la mayor complejidad del asunto, la del municipio de Oñate. En ese caso los NIP se organizaron con motivo de unas consideraciones sobre el futuro del pueblo. El asunto consistía en decidir entre convertir las cuevas de Oñate en fuente de atracción para el turismo o no, y estudiar qué proyectos culturales y turísticos podían llevarse a cabo en Salinas de Añana. Dados los múltiples intereses en juego, a la fase de información se invitó a una empresa de servicios turísticos, un grupo de espeleología, representantes de partidos políticos, un grupo ecologista, una sociedad vecinal, algunos particulares y un técnico del Gobierno Vasco. Existían cuatro posibles proyectos que fueron analizados en función de diversas variantes, como el recorrido a través del interior de la cueva, el acceso exterior (para vehículos y viandantes), la financiación, el impacto ambiental, la estética, el plazo de ejecución, el valor natural, el interés científico y la necesidad de servicios complementarios. Finalmente, el grupo constituido en NIP deliberó, y se decantó por uno de los proyectos.

Las decisiones tomadas en los NIP carecen de fuerza vinculante para la Administración, pero los Ayuntamientos se han visto obligados a tener en cuenta de una u otra forma las conclusiones extraídas, inclinándose por ellas en muchas ocasiones.

Obviamente, este sistema no es un método perfecto o acabado, sino que se trata simplemente de un ejemplo de las innumerables formas con que se pueden implementar sistemas de democracia discursiva. Las ventajas que un modelo de participación como los NIP presentan respecto a la democracia representativa son significativos:

- Permite plantear todos los aspectos de un tema, contemplando tanto sus costes como las repercusiones sobre otros asuntos (ranking de prioridades) y sobre las personas afectadas. Suministra a las partes una información transparente, que crea confianza y evita malentendidos que podrían derivar en un bloqueo o rechazo del proyecto, como ocurre con otros mecanismos de participación como el referéndum. 
- Mientras que en los mecanismos convencionales de participación suele darse una sobrerrepresentación de la clase media-alta y de ciertos grupos de edad, ahora se garantiza una adecuada representatividad de todos los grupos sociales. Se evita además que, como ocurre con otros mecanismos como la exposición pública, sólo participen en el proceso los grupos más directamente afectados o los grupos más militantes.

- Permite una participación real, lo que genera a la vez un mayor interés por la vida pública (y los asuntos ambientales) y una mayor legitimidad de las medidas adoptadas.

\section{Ecología y ciudadanía}

La globalización económica y el consecuente incremento de los flujos migratorios hacia los países económicamente desarrollados, han puesto de manifiesto más claramente que nunca la insuficiencia del concepto de ciudadanía que manejamos. Por ciudadanía podemos entender aquel status atribuido a quienes son miembros de pleno derecho de una comunidad. Se trata pues de un presupuesto necesario, exigido por el Ordenamiento de un Estado, para ser pleno titular de los derechos y obligaciones reconocidos por el mismo. Y esa condición de ciudadano se encuentra vinculada a su vez al previo requisito de la nacionalidad. Así entendida, y tal y como ha puesto de manifiesto un amplio sector de la doctrina, el concepto de ciudadanía es un importante factor de exclusión en las sociedades actuales, ya que sitúa a los no nacionales en un status jurídico inferior con respecto al resto de la población, lo cual no deja de ser paradójico en un Estado que, como el español, se autodefine como democrático.

Esta situación trae consigo nefastas consecuencias para aquellas personas consideradas extranjeras por el Ordenamiento jurídico, y también incide negativamente desde el punto de vista de la ecología política. Podemos decir que la ciudadanía es otro de los "déficit" que presentan las democracias liberales y el propio concepto de Estadonación.

En primer lugar, el concepto de ciudadanía provoca una subrepresentación de los ciudadanos en temas ecológicos, ya que implica una representación de carácter territorial, lo que no incentiva la preocupación por los temas medioambientales ${ }^{75}$. En segundo término, porque perjudica los intereses de los no ciudadanos, a quienes se les niegan también los derechos de tipo medioambiental.

Para solucionar estos problemas derivados del concepto de ciudadanía en el ámbito ecológico, y extender la posibilidad de participación política a todos los afectados, se ha propuesto la creación de un "distrito electoral medioambiental", que incluiría a todos los individuos que tienen un interés vital en los resultados que deriven de una determinada decisión. Como señala VALENCIA SÁIZ, es necesario "concebir la ciudadanía más desde una perspectiva basada en la responsabilidad moral y en la esfera pública, que en una definición formal-legal del Estado, entre otras cosas, porque cuando se habla de problemas medioambientales hay que considerarlos, tanto en relación a otras especies como en relación a las generaciones futuras" ${ }^{\$ 7}$.

\footnotetext{
${ }^{75}$ VALENCIA SÁIZ, A., "Democracia, ciudadanía y ecologismo político”, op. cit., p. 87.

${ }^{76}$ Ibídem.
} 


\section{LA RESPUESTA NEOLIBERAL: ECOLOGÍA DE MERCADO}

\section{Capitalismo, neoliberalismo y crisis ecológica}

Según F. A. HAYEK, padre intelectual del neoliberalismo, son los individuos persiguiendo sus propios intereses y beneficios quienes deben determinar la marcha de la sociedad. En una situación ideal, estos objetivos deben alcanzarse a través de la interrelación de los individuos en el Mercado, de forma espontánea y en régimen de plena libertad individual. Esta libertad es definida en términos negativos, como ausencia total de coacción, de modo que el papel del Estado debe reducirse a garantizar los derechos económicos de los individuos, que son considerados como la base de todos los demás derechos. Cualquier intromisión del Estado o cualquier otro agente en el Mercado libre es considerada como un ataque ilegítimo a la libertad personal.

Estos postulados han sido ampliamente desarrollados en las últimas décadas por autores como Guy Sorman, Robert Nozick, Karl Popper, Francis Fukuyama o M. Friedman. Además, las políticas neoliberales han tenido aplicación práctica de forma más o menos explícita en los años ochenta y noventa, principalmente por Margaret Tatcher y Ronald Reagan, y también, en mayor o menor medida, en casi toda Sudamérica. Actualmente, en el contexto de la globalización económica, este tipo de receteas económicas parecen inspirar las decisiones de instituciones supranacionales como el FMI, el Banco Mundial y la OMC, y son los pilares sobre los que se construyen las zonas de libre comercio en Europa Occidental y Norte América.

Este tipo de ideología, en la que los derechos personales son reducidos a los derechos del Mercado y la libertad es restringida a la libertad de comprar y vender, ha sido acusada de generar grandes desigualdades sociales, de propugnar un individualismo extremo e insolidario, y, en lo que ahora nos interesa, de ser en buena medida la responsable de la espectacular aceleración del deterioro ambiental, al perseguir el desarrollo económico por encima de cualquier otro objetivo. Lejos de quedar indiferentes ante esta última acusación -entro otras cosas, porque la consciencia generalizada sobre la crisis ecológica no se lo hubiera permitido- varios autores han elaborado una serie de teorías sobre los postulados básicos del neoliberalismo, tratando de demostrar que, en realidad, la propiedad privada y el libre mercado son las medidas más adecuadas para garantizar la conservación del medio. Se trata del denominado neoliberalismo ambiental o Ecología de mercado.

Es conveniente puntualizar que la Ecología de mercado es algo distinto a lo que más arriba definimos como el proyecto del capitalismo verde -el cual parecía ser el objetivo de la actual política ambiental en el Estado español y otros de nuestro entorno-. No son conceptos sinónimos porque, en primer lugar y como indica GUDYNAS, capitalismo no es lo mismo que neoliberalismo. La neoliberal es sólo una de las múltiples opciones que caben dentro del capitalismo, que "exagera, dogmatiza y globaliza" algunos de los rasgos esenciales de éste ${ }^{77}$. Además, la doctrina que apuesta por un capitalismo verde exige, según vimos, la introducción de ciertas correcciones o

\footnotetext{
${ }^{77}$ Esto no significa que el capitalismo, en general, no presente consecuencias tan negativas a nivel social o ambiental como el neoliberalismo, pues ambos se asientan sobre el mismo paradigma desarrollista. Pero, como señala este autor, una adecuada comprensión de estos dos fenómenos exige diferenciar lo que son dos realidades al menos parcialmente distintas. GUDYNAS, E., "La privatización de la vida...", op. cit.
} 
límites a los derechos de libertad de empresa y propiedad privada para garantizar algunos objetivos conservacionistas. La Ecología de mercado no postula la adopción de medidas correctoras ni el establecimiento de ningún tipo de límite. Al contrario, busca fortalecer la propiedad privada y la libertad de iniciativa empresarial como principios absolutos, para así lograr la preservación ambiental.

No obstante, si el neoliberalismo "exagera y dogmatiza" los fundamentos del capitalismo clásico, es evidente que ambos modelos parten de planteamientos comunes que deben ser reconsiderados desde la perspectiva ecológica.

\section{- Mercado capitalista y ecología}

Al ocuparnos de la vigente política ambiental hemos apuntado la idea de que, realmente, capitalismo y ecología podrían ser dos ideas antiténticas e irreconciliables. Las razones que nos llevan a sostener tal afirmación atañen a los fundamentos mismos de la ideología capitalista, a su concepción de la naturaleza y su forma de valorización de los recursos y daños ambientales, así como a la idea de progreso sobre la que se sostiene, y que son del mismo modo el sustrato de las tesis neoliberales.

Forjada en el optimismo tecnológico del siglo XIX, la teoría económica capitalista se construye sobre la pretensión de un crecimiento continuo de la productividad, impulsado por el libre juego de un mercado competitivo y la aplicación de nuevas mejoras técnicas a los procesos productivos. Progreso es identificado con crecimiento económico, que se instituye en el principal (y quizá único) objetivo del sistema económico.

El paradigma desarrollista, es decir, el incremento constante del consumo a través de la creación de nuevas necesidades, exige la implicación de un creciente número de factores y recursos en el proceso productivo. En esencia, conlleva la extensión a toda la realidad de la cualidad de mercancía (entidad apta para su intercambio en el Mercado). Sin embargo, esta idea incurre en graves contradicciones, dada la existencia de realidades que, por su propia naturaleza, no son reductibles a tal consideración. La crítica marxista ha centrado su atención en el error que supone reducir el trabajo a la categoría de mercancía, pero lo mismo puede sostenerse respecto a la tierra (naturaleza) ${ }^{78}$. Tierra y trabajo son insertados en el Mercado como bienes aptos para la venta, en el cual encuentran su valoración económica. Pero ni tierra ni trabajo cumplen las condiciones básicas para ser consideradas meras mercancías. Como indica BERMEJO,

el trabajo no es más que una de las manifestaciones de la vida humana, la cual no ha sido creada para la venta, ni se puede desgajar del resto de las manifestaciones de la vida, y no puede ser almacenado, ni puesto en circulación. La tierra tampoco ha sido

\footnotetext{
${ }^{78}$ El propio Marx advirtió en El Capital que "todo progreso en el arte de esquilmar al obrero, sino también en el arte de esquilmar la tierra [...] es a la vez un paso dado en el agotamiento de las fuerzas perennes que alimentan dicha fertilidad [...] por lo tanto la producción capitalista sólo puede desarrollar la técnica y la combinación del proceso social de producción, socavando a la vez las dos fuentes originales de toda riqueza: el hombre y la tierra”. MARX, K., El Capital, Fondo de Cultura Económica, México, 1973.
} 
creada para la venta, y sus funciones, que no pueden ser aisladas, desbordan ampliamente las de ser fuente de recursos y sumidero de residuos ${ }^{79}$.

El origen del capitalismo supuso, al unísono, la aniquilación de las formas de trabajo orgánicas existentes en la sociedad precapitalista y la progresiva desaparición de las formas de explotación de los recursos naturales adaptadas a nivel local. Si tradicionalmente el trabajo y la tierra no estuvieron separados porque vida y naturaleza constituyen un todo articulado, el Mercado, al convertir el trabajo y la tierra en mercancías, tiende a romper esta articulación.

La reducción de la naturaleza, o las partes aprehensibles de la misma, a bienes de intercambio mercantil está ligada a una segunda idea: la consideración de los daños ambientales ocasionados por el proceso productivo como efectos externos o externalidades en relación al mismo. Esta teoría se remonta a los años veinte, cuando el economista A. C. PIGOU acuñó el concepto de deseconomía externa como definición de la diferencia entre el coste privado y el coste social de las actividades económicas. Si el primero expresa el coste que debe soportar un agente económico para lograr la producción, el segundo hace referencia al coste que soporta el conjunto de la sociedad a consecuencia de dicha producción. Los daños ambientales se incluirían entre estos daños a terceros. A partir de ahí, la doctrina capitalista considera que todo efecto externo puede recibir una valoración económica suficientemente justificada. La forma de alcanzar esa valoración motiva gran parte de las diferencias dentro de las teorías ambientalistas liberales, y, concretamente, es la clave de la distinción entre lo que aquí hemos llamado Capitalismo verde y la Ecología de Mercado.

La doctrina neoliberal propone la plena privatización de los recursos ambientales, otorgando derechos de propiedad sobre la totalidad de los elementos naturales, confiando en que la actividad del Mercado les asignará precios idóneos, que internalicen los costes externos. En cambio, quienes abogan por una cierta intervención estatal, reconocen que es necesaria la intervención pública en ese proceso de formación de nuevos precios. La ecotasa sería el ejemplo más claro de ese tipo de intervención.

Como puede apreciarse, se trata de planteamientos distintos pero con una base común, en torno a la idea de crecimiento económico continuo y la internalización ex post de los efectos "externos" del proceso de producción. Fundamento al que se le puede plantear una crítica empírica, escueta pero contundente: si al hacer las cuentas del crecimiento económico se contabilizaran-realmene-, incluso de manera muy imperfecta y parcial los "costes externos" de tipo social y sobre todo ambiental, "resultaría que en nuestra actual economía del despilfarro llevamos ya mucho tiempo menguando en lugar de creciendo" $" 80$.

${ }^{79}$ BERMEJO, R., "Ecología versus mercado capitalista”, en VV.AA., De la economía a la ecología, op. cit., p. 47.

${ }^{80}$ Según cálculos de la propia OCDE, a mediados de los años noventa la tasa de crecimiento económico general de los países industrializados habría disminuído entre el 3 y el 5\% si se restasen los costes de contaminación (tan sólo los de contaminación) producida junto con el producto social. RIECHMANN, J., “Desarrollo sostenible: la lucha...”, op. cit., pp. 29 y 30. 


\section{Fundamentos de la Ecología de mercado}

COASE publicó en 1960 un artículo titulado "El problema del coste social”, en el que planteaba que, si la propiedad de un recurso ambiental está bien definida, agresor y agredido ambiental podrían llegar a acuerdos de compensación monetaria satisfactoria para ambas partes al margen de cualquier intervención pública. Como decíamos, a través de este mecanismo los impactos ambientales dejan de ser externalidades, se convierten en valorables e intercambiables, y se puede alcanzar la solución más económica dentro del Mercado. Estas tesis han sido defendidas por un conjunto de autores agrupados en la Escuela de los derechos de propiedad, siendo bautizada como Ecología de Mercado.

Como primera precisión sobre los razonamientos de esta corriente hay que advertir que, en realidad, estas teorías no aportan ninguna innovación a los fundamentos neoliberales. No introduce nuevas políticas o nuevos principios, sino que se limita a poner de manifiesto nuevas virtudes, ahora de tipo ecológico, de sus tradicionales recetas mercantilistas y privatizadoras. Sus textos están escritos habitualmente como una respuesta contundente y directa frente a los ataques contra el neoliberalismo, contra los postulados del movimiento ecologista y del intervensionismo estatal con fines conservacionistas.

En efecto, buena parte de los esfuerzos del ambientalismo neoliberal se dirige a negar cualquier competencia pública en la protección del ambiente. Como toda doctrina neoliberal, no admite el intervencionismo estatal más allá de la defensa de los derechos individuales, y por tanto, niegan que la defensa y promoción del ambiente y los recursos naturales sea competencia del Gobierno, como garante del bien común. Es más, afirma que la intervención del Estado a menudo agrava los problemas ecológicos, debido principalmente a una deficiente información y una errónea política de incentivos. Según estos autores, las agresiones más importantes al entorno natural, lejos de ser un resultado inevitable del desarrollo económico y del funcionamiento del Mercado, aparecen cuando el Estado interviene de forma sistemática a través de mecanismos coactivos. Por otro lado, su crítica al ecologismo se centra en tildar de catastrofistas sus advertencias a cerca del deterioro ambiental, negando su validez, o al menos poniendo en duda la inmediatez de sus efectos a escala planetaria. Acusan además al ecologismo de poner un exagerado énfasis en el daño ambiental causado por el sector privado, y de ignorar que "el mayor depredador es, muchas veces, el Estado"

${ }^{81}$ LARAIN, L., HURTADO, J. y RAMÍREZ, P., Ecología de Mercado, Fundación Libertad y Desarrollo-Trineo S.A., Santiago de Chile, 1995. Algunas críticas que los economistas neoliberales dirigen contra el ecologismo son simplemente demagógicas, carentes de fundamento, o centradas en posturas que sólo han sido defendidas por algún sector aislado, y que estos autores generalizan injustificadamente. Por ejemplo, puede leerse entre sus textos que el ecologismo postula un control indiscriminado de la población humana -postura defendida únicamente por algún autor representante de la Ecología profunda-, o el exterminio de ciertas especies animales en aras de la conservación de otras especies vegetales. Autores como F. L. SMITH -uno de los principales exponentes de la Ecología de mercado- acusan al ecologismo de haberse convertido "en una religión, en una especie de fe laica que trasciende todo debate lógico y racional", y de creer que "un mundo sin seres humanos y sin industrias, sería infinitamente mejor". SMITH, F.L., Ecología de Mercado, editado en España por la Fundación para el análisis y los estudios sociales, 1996 (Fundación de la que, por cierto, es presidente José María Aznar). 
En todo caso, la Ecología de Mercado prioriza los impactos de carácter global frente a los locales, al considerar que son ésos los que pueden incidir más profundamente en las economías mundiales.

A nivel teórico, el ambientalismo neoliberal coincide básicamente con las corrientes que dentro de la Ecología biológica propugnan la denominada Ecología del caos. Ésta rechaza la vieja noción de que las comunidades de plantas y animales son una entidad real compuesta por un conjunto de especies; al contrario, considera que las comunidades no existen en sí mismas, y que cada individuo lucha en la naturaleza por su propio beneficio. Las comunidades son sólo el resultado aparente de los comportamientos egoístas de múltiples individuos, y la naturaleza, en realidad, no tiene un orden, sino que en su esencia es errática y caótica ${ }^{82}$.

A partir de estos planteamientos, las propuestas de la Ecología de Mercado pasan por un fortalecimiento a ultranza del derecho de propiedad privada, que debe extenderse a todos los elementos de la naturaleza, y el respeto absoluto a la libertad de Mercado. Básicamente, la ventaja de la propiedad privada de los recursos sería que el propietario del mismo tiene los incentivos necesarios para mantener su productividad: cualquier deterioro en la calidad del recurso supondría una pérdida financiera para el propietario, obligado a invertir en su restauración si desea continuar su explotación. En cuanto al funcionamiento del Mercado, su premisa es que existen procesos espontáneos movidos por la propia fuerza creativa de la función empresarial, que tienden a que el desarrollo económico y social de la especie humana se coordine y ajuste de una manera eficiente y respetuosa con el resto de las especies y elementos del entorno natural. De esta forma, y sobre la base de una precisa y eficaz defensa de los derechos de propiedad-que es la función de los poderes públicos-, los problemas medioambientales reciben la mejor solución posible a través de los mecanismos del Mercado. Así,

\footnotetext{
una vez imputados todos los costes a sus responsables económicos, el principio del equilibrio general neoclásico asegura que el juego de los agentes económicos en el mercado conducirá al sistema hacia sucesivos puntos óptimos de equilibrio en niveles de producción crecientes, en cada uno de los cuales la asignación de los recursos de todas clases será la mejor de las posibles ${ }^{83}$.
}

Un argumento clásico del neoliberalismo es que sólo un régimen de propiedad privada sobre todos los elementos naturales puede evitar lo que GARDIN denominó "La Tragedia de los Comunes". Este fenómeno, que supuestamente afecta a todo bien que tiene la categoría de colectivo, se resume en el axioma de que un bien de acceso libre es un bien en el que nadie tiene interés en garantizar ni su mantenimiento ni su renovación, ya que se trata de iniciativas, que por el principio de libre acceso, no puede tener ningún valor en el Mercado. La consecuencia es que este tipo de bienes están condenados a ser sobreexplotados y rápidamente agotados ${ }^{84}$.

\footnotetext{
${ }^{82}$ Un ejemplo paradigmático dentro de esa corriente es BOTKIN y su obra Discordant harmonies. A new ecology for the 21st century, Oxford University Press, New York, 1990.

${ }^{83}$ ESTEVAN, A., "Monetarización del medio ambiente y ecologismo de Mercado", en VV.AA., De la economia a la ecología, op. cit., p. 70.

${ }^{84}$ GHERSI, E., en su trabajo La privatización del mar, publicado en la web del Cato Institute (www.elcato.org), pone como ejemplo los animales marinos objeto de pesca, sobre el siguiente razonamiento: dado que los peces del mar no tiene un propietario privado concreto, "si yo soy un hombre prudente y limito voluntariamente mis capturas para no agravar la sobreexplogación del medio marino, no tengo en realidad ninguna garantía de que los demás van a hacer lo mismo. Por ello, yo, al
} 
Estos efectos negativos, entonces, sólo podrían evitarse a través del otorgamiento de títulos de propiedad privada, evitando así el régimen de titularidad común. Los partidarios de la Ecología de Mercado indican los rasgos que debe tener el derecho de propiedad privada para ser un instrumento válido de cara a la protección de los recursos naturales:

- Universalidad, de modo que todos los recursos sean poseídos por alguien (incluidos el aire, el mar, etc.)

- Exclusividad, consistente en la posibilidad que dicho propietario tiene de excluir a los demás del consumo y uso del bien en cuestión.

- Transferibilidad; de acuerdo con la máxima capitalista, por medio del intercambio se asigna el control de los recursos a quienes tienen la capacidad y la motivación para utilizarlos de la forma más eficiente.

- Implantación de un adecuado sistema de responsabilidad por daños e intromisiones en la propiedad ajena. De esta forma los protagonistas económicos tendrán los incentivos adecuados para desarrollar nuevos métodos que reduzcan la contaminación, que en definitiva supone una intromisión ilegítima en la propiedad ajena. Esto permitiría al mismo tiempo una más rápida evolución de las iniciativas e innovaciones ecológicas.

Otra ventaja que, según esta teoría, tiene la iniciativa privada es que ésta permite proteger valores y causas ecológicas para las que falta apoyo popular. Un régimen de propiedad privada permitiría que incluso los valores ecologistas más minoritarios pudieran beneficiarse de protección, mientras que bajo un régimen politizado sólo estarían protegidas aquellas causas que obtuvieran un apoyo popular suficiente ${ }^{85}$.

igual que el resto de pescadores, trataré de hacer todo lo que pueda para pescar lo más posible, con el fin de evitar que lo que yo no pueda capturar, lo capturen por mí los demás". Como se ve, es un razonamiento inspirado en la "teoría de los juegos" que tanto gusta emplear a los autores neoliberales.

${ }^{85}$ En este sentido, SMITH pone el ejemplo de la montaña estadounidense Hawk Mountain. En la época en que el Gobierno de los Estados Unidos consideraba a los halcones aves rapaces indeseables y promovía su eliminación, un grupo de particulares, no conformes con esa política, decidió comprar una cresta montañosa en la que habitaban numerosos halcones. Construyeron una cerca y contrataron un guarda. Smith señala que actualmente Hawk Mountain se ha convertido en un centro para el estudio de aves rapaces conocido en el mundo entero, mientras que en otros lugares el halcón desapareció. De hecho, los autores neoliberales son muy dados a la utilización de ejemplos concretos para defender sus razonamientos. GHERSI detalla las ventajas que una privatización de todos los recursos y superficies marinas tendría para la protección de ese ecosistema -el interés personal sobre el mismo garantizaría una explotación óptima de estos recursos, y el mantenimiento de las especies con riesgo de extinción-. Pero quizá, el ejemplo más conocido es el descrito por SMITH en relación con el elefante africano. Expone cómo esta especie ha sido perseguida y masacrada, lo cual según la versión mayoritaria se debe al alto precio que el marfil alcanza en el Mercado. La respuesta de los organismos internacionales y de muchos Estados africanos, señala, ha sido la de excluir el Mercado respecto de ese producto, prohibiendo el tráfico de marfil. Sin embargo, el resultado ha sido que, debido a la caza furtiva, el elefante sigue corriendo grave peligro en casi toda África. Opuestamente, describe cómo la estrategia seguida en los Parques Naturales de Zimbawe ha permitido un espectacular crecimiento de la población de esta especie: la táctica del Gobierno de ese Estado ha consistido en adjudicar a los Consejos Tribales de las comunidades indígenas residentes en esos Parques Naturales derechos de propiedad sobre los elefantes -derechos de caza y a percibir un canon por cada animal matado-. La preocupación a partir de entonces de los habitantes de esas zonas por erradicar la caza furtiva ha permitido una explotación 
En resumen, la Ecología de mercado sostiene que sólo mercados abiertos y competitivos permiten que todos los costos, incluidos los ambientales, sean tenidos en cuenta. El mecanismo para lograrlo, como irónicamente describe GORDILLO FERRÉ, puede resumirse en la consigna: "iprivaticemos el mundo!"86.

\section{Crítica a la Ecología de mercado}

Los planteamientos de la Ecología de mercado han sido ampliamente contestados, manteniendo la acusación de que es precisamente el tipo de razonamientos neoliberales y el desarrollo sin límites lo que en buena medida nos ha situado en la actual situación de deterioro ambiental. $\mathrm{Y}$ es que, ciertamente, sobran argumentos para rebatir sus conclusiones. Existen graves deficiencias en sus planteamientos, tanto en el plano axiológico como en el práctico, que agravan hasta la ruptura la tensión entre los conceptos de capitalismo y ecologismo.

En primer lugar, hay que referirse a su estrecha y unidimensional visión de la naturaleza como un mero recurso económico. El neoliberalismo no otorga valor alguno a la naturaleza en sí misma considerada, sino que es vista sólo como medio para la satisfacción de las necesidades humanas -esencialmente refinables, según su doctrina-, como una fuente de crecimiento económico. Claro está, según su teoría lo humano queda al margen del concepto de naturaleza, que se define precisamente de forma negativa, como lo no humano.

Detrás de esos planteamientos descansa una concepción fuertemente antropocéntrica - más que ninguna otra teoría- de la realidad. Como advierte GORDILLO FERRÉ, el derecho a la propiedad privada, en conexión con el principio de soberanía de los Estados, tiene como presupuesto filosófico un marcado antropocentrismo. Herederos del individualismo radical del liberalismo clásico, aunque quizá más radicalizado, la propiedad privada entendida de forma absoluta sitúa al individuo humano, a su voluntad y a sus deseos, en el centro de todo el universo social, relegando todo lo demás a un segundo plano. De ahí que la Ecología de Mercado sólo considere los aspectos ambientales que tienen un valor monetario directo, obviando otros aspectos de importancia indiscutible, como el valor paisajísitico, la vida salvaje o la regulación del clima. Por otro lado, esta cosmovisión lleva inevitablemente a la irresponsabilidad social, "lo que implica no sentirse responsable por las consecuencias que el ejercicio de los propios derechos pueda tener en la vida de otras personas" $" 87$. Irresponsabilidad que será aún más patente respecto a las generaciones futuras, que son un sujeto fundamental al hablar de la protección ambiental.

Su perspectiva simplificadora lleva a estos autores, en el plano argumentativo, a plantear ejemplos sencillos en el que se involucran pocos factores, lo que choca con la realidad de la mayoría de los problemas ambientales, esencialmente complejos.

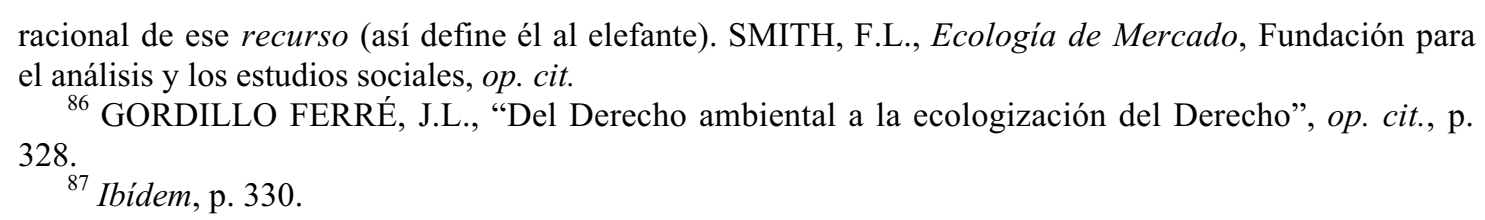


Descendiendo a un plano más concreto, la tesis sobre la valorización monetaria de los daños ambientales y su internalización a través de las transacciones en el Mercado plantea serias debilidades teóricas. Empezando por lo más obvio, es fácil constatar que existe un gran número de recursos que los individuos no están en condiciones de intercambiar en el Mercado, bien por no ser apropiables por naturaleza, o bien por su carácter vital, que les hace no ser sustituibles por ningún otro valor ${ }^{88}$. Pensemos en cómo podrían definirse derechos de propiedad sobre el clima o sobre la capa de ozono, y cómo internalizar los costes derivados de su destrucción.

Por otro lado, como decíamos, el discurso neoliberal excluye necesariamente a las generaciones futuras, que no están presentes en el momento en que se produce la valorización de los recursos y daños ambientales. En este sentido, cualquier monetarización de la naturaleza, realidad esencialmente atravesada por el factor temporal, resulta arbitraria desde la perspectiva de las futuras generaciones y el posible aprovechamiento que en ese momento pueda hacerse de sus recursos.

Las pretendidas virtudes de la propiedad privada sobre los ecosistemas para lograr su preservación no son en absoluto generalizables. Es fácil imaginar casos en que, desde la perspectiva del estricto interés individual inmediato, al propietario de un recurso puede serle más beneficioso su explotación hasta el agotamiento que un uso sostenible del mismo. De hecho, existen numerosos ejemplos de este tipo de comportamientos, como la tala indiscriminada de masas forestales adquiridos por agentes privados, o la explotación por multinacionales agroalimentarias de tierras en el Sur hasta su extenuación, seguida de la adquisición de nuevos terrenos a bajo precio. El propietario puede conseguir un beneficio económico personal e inmediato, mientras que la generalidad se ve notablemente perjudicada. En un sistema basado en una competencia voraz y excluyente, regido por la máxima de crecer o ser expulsado del Mercado, los intereses conservacionistas (colectivos) cederán en un elevado número de casos ante el interés individual del propietario. Parece que lo más adecuado para lograr una verdadera conciencia sobre los problemas ecológicos no es precisamente fomentar la competitividad y el individualismo extremo, sino más bien la cooperación y la solidaridad con las generaciones presentes y futuras.

Los defensores de la Ecología de mercado parten de una afirmación que posiblemente es cierta: las políticas centralizadoras no sirven para lograr la preservación ambiental. Pero su alternativa es, probablemente, todavía más ineficaz. Su propuesta consiste en implantar sistemas descentralizados, pero el problema radica en que esos sistemas están regidos por la lógica del interés individual. Ese exclusivo interés individual provoca que, como decíamos antes, el capitalismo neoliberal no tenga en cuenta ni a los demás, ni al futuro.

Respecto a esa lógica individual, JAKOBS señala que, en realidad, en el libre Mercado la obtención de beneficios no se persigue sólo por codicia, sino también para mantener la supervivencia de la empresa. A todo empresario se le plantea un dilema entre beneficios o extinción, que le empuja a la búsqueda constante del crecimiento. El resultado agregado de todos los planes empresariales para aumentar el negocio, impulsa al sistema en su conjunto hacia el crecimiento constante del uso de los recursos

${ }^{88}$ ESTEVAN, A., "Monetarización del medio ambiente y ecologismo de Mercado", en VV.AA., De la economia a la ecología, op. cit., p. 73. 
naturales y de la emisión de desechos. En esta situación, la asignación de los recursos se produce como resultado inconsciente de las decisiones privadas de millones de directivos de empresas y de los consumidores, que no tienen en cuenta las decisiones de los demás, sino sólo sus intereses individuales ${ }^{89}$.

Un contundente argumento en contra de la viabilidad de la Ecología de Mercado es aportado por la propia experiencia. Medidas de este tipo se han puesto en marcha a lo largo de toda Centro y Sudamérica, sin que ello haya subsanado los graves problemas ecológicos de esa zona del planeta. Al contrario, como han demostrado los estudios de autores sudamericanos interesados en la Ecología social como Eduardo GUDYNAS o Enrique LEFF, los ha recrudecido notablemente. Estos autores señalan que, quizá, la influencia más fuerte de las políticas neoliberales se ha producido en Chile, pero la gestión estatal esta fuertemente influenciada por estas ideas en otros países, especialmente Argentina, Bolivia, México, Perú, Uruguay y Venezuela, y la misma perspectiva esta detrás de las reformas en marcha en países como Colombia o Nicaragua. Aunque en la mayoría de los casos no se han adoptado políticas neoliberales puras, esas ideas han influido notablemente en la política de todos esos Estados, con consecuencias dramáticas ${ }^{90}$. Los resultados son más de 200 millones de habitantes en una situación de miseria extrema en toda América Latina, el desplazamiento de las comunidades indígenas a causa de la incursión de empresas multinacionales petrolíferas y madereras en zonas hasta hace poco intactas, y una alarmante esquilmación de los ecosistemas de la mano de industrias norteamericanas y europeas, principalmente.

Y las acciones en defensa de los ecosistemas no están viniendo precisamente de los partidarios de la Ecología de mercado -que cuentan con un número importante en Sudamérica-, sino principalmente de los propios pueblos indígenas. En los últimos años se han desarrollado importantes iniciativas por parte de este sector de la población que está sufriendo especialmente las consecuencias del neoliberalismo. Frente a esta situación y la indiferencia del Estado ante sus demandas, han desarrollado proyectos autogestionarios en ámbitos como la educación o la sanidad, y han promovido campañas de rechazo ante instrumentos colonizadores como los alimentos transgénicos, o las industrias que tratan de desplazarles por la fuerza de sus propios hábitats ${ }^{91}$.

En este sentido, como venimos sosteniendo, los costes sociales no pueden ser olvidados en el discurso de la sostenibilidad. La aplicación de las tesis neoliberales llevan generando una creciente exclusión social dentro de los Estados desarrollados, y una alarmante precarización de las condiciones de vida en los pueblos del Sur. El ansiado crecimiento económico que persiguen los dogmas neoliberales no supone un reparto de la riqueza creada, sino su acumulación en un número cada vez más reducido

\footnotetext{
${ }^{89}$ Citado por GORDILLO FERRÉ en "Del Derecho ambiental a la ecologización del Derecho “, op. cit., p. 324.

${ }_{90}$ Precisamente, un argumento utilizado por los neoliberales es que, realmente, el modelo que proponen no se ha llegado a aplicar, pues incluso en esos Estados sudamericanos la intervención política sigue siendo notable. Sin embargo, los nefastos resultados ambientales y sociales que están trayendo consigo ese tipo de políticas, no permite pensar que una radicalización de las mismas vaya a cambiar el rumbo de los acontecimientos, sino más bien al contrario.

${ }^{91}$ Una de las luchas más significativas fue la emprendida por la tribu de los Uwa, en Bolivia, quienes amenazaron con un suicidio colectivo de 5000 personas si la petrolera "Oxycol" no cesaba las perforaciones de pozos e los territorios que habitaban. La presión internacional consiguió parar las pretensiones de la petrolera, pero en muchos otros casos no ha ocurrido lo mismo.
} 
de manos. La experiencia de la mundialización económica parece dar la razón a Marx, respecto a que el capitalismo tiende inevitablemente al monopolio. La Ecología de Mercado, que en definitiva sólo supone más de lo mismo, sólo conduciría a exacerbar las desigualdades sociales e internacionales. Tal y como explica ESTEVAN, internalizar los costes externos significa elevar los precios de los recursos para reducir su consumo hasta llegar a un punto de equilibrio que se supone sostenible desde el punto de vista ambiental, y óptimo desde el punto de vista económico. Este proceso acaba por modificar el sistema de precios. Es más, desde esa óptica, puede decirse que sólo cambios drásticos en la estructura de precios puede llevar a reducciones significativas en los consumos de recursos naturales. Lo cual implica que sólo las clases sociales más poderosas podrían acceder a los recursos en una previsible situación de escasez $^{92}$.

SMITH no duda en afirmar que el respeto a la propiedad privada y al libre Mercado permitiría el desarrollo de tecnologías con las cuales protegerse de los efectos derivados de fenómenos como el cambio climático. Aún admitiendo la improbable veracidad de esta afirmación, podemos preguntarnos: ¿quién se beneficiaría de esta tecnología en un mundo completamente privatizado?

\section{- Ecología y subdesarrollo: la deuda ecológica}

Al tratar los efectos sociales de las políticas neoliberales debemos hacer especial hincapié en la profundización de las diferencias Norte-Sur, en la configuración de un panorama internacional radicalmente desigual, en el que un pequeño sector de la población mundial acapara un enorme porcentaje de los recursos disponibles del planeta. En este sentido, un conjunto de autores han sostenido que el fenómeno del subdesarrollo debe ser explicado, no sólo desde una perspectiva económica -como resultado directo de una relación de intercambio de bienes absolutamente injusta entre países ricos y pobres-, sino también ecológica. Así, GARRIDO PEÑA y GONZÁLEZ DE MOLINA señalan que debe hacerse hincapié en la presión y apropiación crecientes de los recursos, tanto humanos como materiales, de los países pobres por parte de los ricos, ya que el control de las fuentes de energía y materiales y la explotación de la mano de obra desempeñan un papel estratégico en el crecimiento económico de los países subdesarrollados. Estos autores afirman que "El comercio internacional ha permitido a los países industrializados abaratar considerablemente no sólo su mano de obra (...) sino también los subsidios energéticos y los materiales consumidos en el mantenimiento y en la expansión del Capital. Su control ha resultado absolutamente vital para su reproducción ampliada, para engrasar el mecanismo de la acumulación capitalista"93. Por lo tanto, como indica MARTÍNEZ ALIER, la historia ecológica de Latinoamérica podría explicarse como una historia de producción de exportaciones a expensas del capital natural, una historia de dependencia ecológica ${ }^{94}$. Las consecuencias de esta apropiación imperialista de recursos y energía han sido catastróficas: la

\footnotetext{
${ }^{92}$ ESTEVAN, A., "Monetarización del medio ambiente y ecologismo de Mercado", op. cit., p. 74.

${ }^{93}$ GARRIDO PEÑA, F. y GONZÁLEZ DE MOLINA, M., "La cuestión nacional desde la ecología política. Algunos elementos de análisis”, Ecología Política No13, 1997, pp. 138 y 139.

94 MARTÍNEZ ALIER, J., De la economía ecológica al ecologismo popular, Icaria, Barcelona, 1992, p. 20.
} 
destrucción de la base de recursos naturales de los países pobres, y como consecuencia, la esquilmación del potencial productivo de sus ecosistemas.

A partir de esta constatación, se ha propuesto que la noción de intercambio desigual debería incluir también esta transferencia desigual de energía y materiales, de capacidad de sustentación, pasando a denominarse intercambio ecológico desigual. Asimismo, se ha acuñado el concepto de deuda ecológica, que no es sino la deuda acumulada por los países del Norte frente a los países del llamado Tercer Mundo por el saqueo de sus recursos, por los daños ambientales no reparados y por la ocupación gratuita del espacio ambiental para depositar sus residuos. La deuda ecológica compensaría con creces la deuda externa que asfixia las economías de los países del Sur, teniendo en cuenta además que la esquilmación ecológica de estos Estados, iniciada en la época colonial, está lejos de haber desaparecido. Las políticas neoliberales en el contexto de la mundialización económica están intensificando este expolio, sumando a las tácticas tradicionales (extracción directa de materiales y depósito de desechos) otras nuevas, como las patentes sobre la vida y la biopiratería.

4. Qué tipo de economía para una sociedad sustentable.

La crítica a los planteamientos económicos actuales sugiere que un modelo social sostenible requiere la superación de los fundamentos de la teoría capitalista. En esta búsqueda de un nuevo planteamiento puede resultar interesante apuntar la existencia de una corriente crítica respecto a la ciencia económica tradicional, cuyos precursores se remontan más de cien años, y que ha sido denominada Economía ecológica. Su nombre deriva de la argumentación que esta corriente ha planteado a los economistas tradicionales, en el sentido de que su estudio debería centrarse en el flujo de energía en la economía sin olvidar los flujos materiales. Proponen la aplicación de conceptos físicos -como la ley de conservación de la materia, y las leyes de la termodinámica- para alcanzar una profunda comprensión de cómo la economía humana está inmersa en los ecosistemas. Se trata de ver la economía, no como una corriente circular o espiral de valor de cambio, sino como un proceso entrópico de energía y materiales, que atraviesa la economía ${ }^{95}$.

GEDDES, PODOLINSKY Y SODDY, entre otros, plantearon ya en el siglo XIX la peligrosa despreocupación de los economistas neoclásicos respecto del marco biofísico en el que necesariamente se inscribe la economía humana. Sus planteamientos han alcanzado el máximo desarrollo en el siglo XX de la mano de GEORGESCU-ROEGEN en su obra La ley de la entropía y el proceso económico ${ }^{96}$. Éste presenta la economía como un flujo entrópico, dentro de un sistema abierto a la entrada de energía, frente a la noción circular del proceso económico, como sistema cerrado desde el punto de vista energético, sostenido por los economistas clásicos. GEORGESCU-ROEGEN plantea que el proceso no es circular, sino unidireccional: "en lo que afecta a esta faceta solamente, el proceso económico consiste en una transformación de baja entropía en alta entropía, es decir, en deshecho irrevocable (...). La conclusión es que, desde el

\footnotetext{
${ }^{95}$ Ibidem, p. 27.

${ }^{96}$ The Entropy Law and the Economic Process, en su título original, publicado en España en la colección Economía y Naturaleza, Fundación Argentaria, Madrid, 1996.
} 
punto de vista puramente físico, el proceso económico es entrópico: no crea ni consume materia o energía sino que solamente transforma baja entropía en alta entropía, es decir, en deshecho irrevocable o, utilizando una expresión tópica, en contaminación"97.

La Economía ecológica plantea la superación de los fundamentos de la economía capitalista desde el punto de vista ambiental, en primer lugar, respecto a la evaluación de las externalidades. La crítica no se basa únicamente en el hecho del desconocimiento actual de las preferencias de los agentes futuros (que motiva la arbitrariedad del valor asignado a los efectos externos), sino que además se basa en la incertidumbre sobre el funcionamiento de los sistemas ecológicos. Este inconveniente, directamente, impide la aplicación del análisis de externalidades, ya que hay efectos externos desconocidos, y otros a los que no se les puede asignar un valor determinado, al no saber ni tan siquiera si son positivos o negativos. Dado que la economía es entrópica, produce el agotamiento de recursos y la generación de desechos, fenómenos que el Mercado es incapaz de valorar con exactitud. Y, en cualquier caso, la asignación a las generaciones futuras de desechos y recursos disminuidos, sin que esas generaciones sean resultado de ninguna transacción intergeneracional, atenta contra el dogma de valoración de los efectos externos a través de los intercambios del Mercado. En definitiva, la economía capitalista se muestra incapaz de integrar a las generaciones futuras, que necesariamente quedan excluídas del debate.

\section{CONCLUSIONES}

Como advertimos al inicio, el resultado del recorrido planteado en este trabajo no son propuestas perfectamente definidas y acabadas. Es posible que el camino hacia la sustentabilidad no pase por un modelo político o económico detallado, sino más bien por la creación de estructuras que plasmen un conjunto de valores, y se muestren abiertas y flexibles a nuevos planteamientos.

Como corolario, podríamos decir que un principio básico para un modelo sostenible debe ser la reintegración del ser humano y su sociedad con el resto de los ecosistemas. Puede que la recuperación de la conciencia de que formamos parte de procesos mucho más amplios, que trascienden las fronteras de lo humano y nos hacen ser parte de un todo en frágil equilibrio, sea la idea fundamental para cualquier proyecto social sostenible. Aquí hemos apuntado las líneas generales que podrían hacerlo realidad, en un plano ético, político y económico.

Desde el punto de vista ético, la reintegración efectiva de la sociedad en su entorno exige la ruptura del paradigma antropocéntrico, no en favor de perspectivas biocéntricas, sino de una cosmovisión que enfatice la complementariedad entre todos los ecosistemas, y entre todos los elementos dentro de los mismos. El objetivo debe ser erosionar la idea excluyente de otredad que opone lo humano y lo no humano, lo

${ }^{97}$ Hay que advertir que, evidentemente, el proceso físico del entorno natural es igualmente entrópico, pero, a diferencia del proceso económico, aquél es automático, en el sentido de que prosigue por sí mismo. El proceso económico depende de la actividad humana, una actividad de selección, que debe alimentarse igualmente de baja entropía. Ésta es la razón de que el proceso económico produzca mayores niveles de entropía (desechos) que la reordenación automática del entorno natural. Ibídem., pp. 352 y 353. 
natural y lo no natural, asumiendo los valores de complementariedad y apoyo muto como principios básicos en el funcionamiento de todo ecosistema, también el social.

En el aspecto político, hemos propuesto una recuperación de lo local, una gestión descentralizada de los recursos y una democracia de tipo sustantivo y directo, que permita a la vez una política de preservación eficaz y una recuperación de la idea de comunidad, de que formamos parte de un ecosistema social, frente al individualismo radical que ha desestructurado dicho ecosistema. La lógica burocrática, la democracia liberal y la propia idea de Estado-nación, deben ser cuestionados en clave ecológica.

Y, por último, la reintegración de los procesos económicos en los ecosistemas que los sustentan pasa por una percepción de los mismos como procesos entrópicos, generadores de altos niveles de entropía que no pueden ser valorados y compensados en términos exclusivamente monetarios. El modelo de economía capitalista es incompatible con cualquier proyecto de sostenibilidad, lo que principalmente se debe al modo de valorización capitalista de la naturaleza (exclusivamente monetaria) y la imposibilidad de internalizar ex post todos los costes ambientales y sociales ocasionados por el proceso productivo.

\section{BIBLIOGRAFÍA CITADA}

AZURZA, "Los sistemas de participación NIP”, en Euskonews, n9, 6-19 noviembre 1998.

BERMEJO, "Ecología versus mercado capitalista", en VV.AA., De la economía a la ecología, en VV.AA., De la economía a la ecología, Editorial Trotta y Fundación $1^{\circ}$ de Mayo, Madrid, 1995.

BIEHL, Las políticas de la ecología social, Virus, Barcelona, 1998.

BIGUES, "La democracia ambiental: un camino complejo", en Biblioteca de ideas (www.iigov.org, página web del Instituto Internacional de Gobernabilidad).

BOOKCHIN, La ecología de la libertad. La emergencia y la disolución de las jerarquias, Nossa y Jara (col. Madre Tierra), 1999.

- "Nosotros los verdes, nosotros los anarquistas" en VV.AA., Teorías y prácticas del ecologismo social, Oxígeno, 2002.

COMMONER, , Science and survival, Viking Press, Nueva York, 1966.

DRYZEK, Rational Ecology. Enviromental and Political Ecology, Oxford, Blackwell, 1987.

- Discursive Democray: Politics, Policy, and Political Science, Cambridge University Press, 1990.

- $\quad$ "Political and Ecological Communication", en Enviromental Politics, N4, 1995, pp. 13-31. 
- $\quad$ "Ecología y democracia discursiva: más allá del capitalismo liberal y del Estado administrativo", en Ecología Política. Cuadernos de debate internacional, nº16, 1998.

ECKERSLEY, Environmentalism and Political Theory: Toward an Ecocentric Approach, Suny Press, Albany (NY), 1992.

"Greening Liberal Democracy: The Rights Discourse Revisited", en DOHERTY, B. y DE GEUS, M. (eds.), Democracy \& Green Political Thought, Routledge, Londres, 1996, pp. 212-236.

ESTEVAN, "Monetarización del medio ambiente y ecologismo de Mercado", en VV.AA., De la economia a la ecología, Editorial Trotta y Fundación $1^{\circ}$ de Mayo, Madrid, 1995.

FERNÁNDEZ DURÁN, Capitalismo global, resistencias sociales y estrategias de poder, Ecologistas en Acción - Movimiento contra la Europa de Maastricht y la globalización económica, Madrid-Pelegrina, agosto 2000.

FUENTES BODELÓN, "Hacia el necesario pacto ambiental", en Revista de Derecho Ambiental, n²4, 2000, pp. 97-111.

GARRIDO PEÑA (comp.), Introducción a la ecología política, Comares, Granada, 1993.

La ecología política como política del tiempo, Comares, Granada, 1996.

GARRIDO PEÑA y GONZÁLEZ DE MOLINA, "La cuestión nacional: una propuesta desde la Ecología Política", en Anales de la Cátedra Francisco Suárez, No31, 1994, pp. 101-110.

- "La cuestión nacional desde la ecología política. Algunos elementos de análisis", Ecología Política No13, 1997, pp. 125-155.

GEORGESCU-ROEGEN, La ley de la entropía y el proceso económico, Colección Economía y Naturaleza, Fundación Argentaria, Madrid, 1996.

GHERSI, La privatización del mar, Cato Institute (www.elcato.org)

GORDILLO FERRÉ, "Del Derecho ambiental a la ecologización del Derecho", en VV.AA., Transformaciones del Derecho en la Mundialización, Escuela Judicial (CGPJ), Madrid, 2000, p. 332.

GUDYNAS, "La privatización de la vida: América Latina ante las nuevas políticas ambientales neoliberales", en www.dei-cr.org/Anteriores/81/pasos81 1.html. Primera versión publicada en la revista Multiversidad, Montevideo (Uruguay).

GUHA, "El ambientalismo estadounidense y la preservación de la naturaleza: una crítica tercermundista", en Ecología Política No 14 , 1997, pp. 33-46

HARMS, "El modelo NIP contra las deficiencias del sistema democrático representativo para responder a los problemas medioambientales", en Ecología Política $\mathrm{N}^{\mathrm{o}} 13,1997$.

MARX, El Capital, Fondo de Cultura Económica, México,1973

HULSMAN, Sistema penal y seguridad ciudadana: hacia una alternativa, Ariel, Barcelona, 1984. 
LARAIN, HURTADO, y RAMÍREZ, Ecología de Mercado, Fundación Libertad y Desarrollo-Trineo S.A., Santiago de Chile, 1995.

LETTERA, Lo stato ambientale: il nouvo regime dele risorse ambientali, A. Giuffrè, Milán, 1990.

LOPERENA ROTA, Los principios del Derecho ambiental, Civitas, Madrid, 1998.

MARTÍN MATEO, Tratado de Derecho ambiental, Trivium, Madrid, 1991 (1 $^{\text {a }}$ edición).

MARTÍNEZ ALIER, De la economía ecológica al ecologismo popular, Icaria, Barcelona, 1992.

MORSE, "Ciudades radicales y revolución social. Entrevista con Janet Biehl”, en VV.AA., Teorías y prácticas del ecologismo social, Oxígeno, 2002.

PÁEZ, "Del desarrollo a la ecología social", en Revista Mad nº1, Dep. de Antropología, Universidad de Chile, septiembre 1999.

PASSMORE, La responsabilidad del hombre frente a la naturaleza, Alianza editorial, Madrid, 1978.

PICONTÓ NOVARES, En las fronteras del Derecho, Dykinson, Madrid, 2000.

RIECHMANN, "Desarrollo sostenible: la lucha por la interpretación”, en VV.AA., De la economía a la ecología, Editorial Trotta y Fundación $1^{\circ}$ de Mayo, Madrid, 1995

RIECHMANN y FERNÁNDEZ BUEY, Ni tribunos. Ideas y materiales para un programa ecosocialista, Siglo XXI, Madrid, 1996.

ROCAMORA GARCÍA-VALLS, Agresividad y Derecho, Bosch, Barcelona, 1990.

RODRIGÁÑEZ, El asalto al Hades. La rebelión de Edipo, $1^{a}$ parte, Traficantes de sueños, Madrid, 2002.

RODRIGÁÑEZ y CACHAFEIRO, La represión del deseo materno y la génesis del estado de sumisión inconsciente, Nossa y Jara (col. Madre Tierra), Madrid, 1995.

"Matricidio y Estado terapéutico", en Archipiélago, cuadernos de crítica de la cultura, $\mathrm{n}^{\mathrm{0}} 25$, pp. 75-82.

- $\quad$ "Por una maternidad antipatriarcal”, en Ekintza Zuzena, n¹9, pp. 39-47.

SANZ RUBIALES, I., "La legitimación de las asociaciones ecologistas en el proceso judicial (Comentario a la STC 34/1994, de 31 de enero)", en Revista de administración pública, $\mathrm{N}^{\mathrm{o}} 141,1996$.

SERRANO MORENO, "Ecología, Estado de Derecho y Democracia", en Anuario de Filosofía del Derecho, 1993.

SMITH, Ecología de Mercado, editado en España por la Fundación para el análisis y los estudios sociales, 1996.

VALENCIA SÁIZ, "Democracia, ciudadanía y ecologismo político", en Revista de estudios políticos, $\mathrm{n}^{\circ} 102$, octubre-diciembre 1998.

VICENTE GIMÉNEZ, (coord.), Justicia ecológica y protección del medio ambiente, Trotta, Madrid, 2002. 